\title{
Fossil Fuel Divestment and Portfolio Performance
}

\author{
Arjan Trinks ${ }^{\text {a, }}$, Bert Scholtens ${ }^{\text {a, b }}$, Machiel Mulder ${ }^{\text {a }}$, Lammertjan Dam ${ }^{\text {a }}$
}

\begin{abstract}
Fossil fuel divestment campaigns urge investors to sell their stakes in companies that supply coal, oil, or gas. However, avoiding investments in such companies might impose a financial cost on the investor because of foregone potentially profitable investments and reduced opportunities for portfolio diversification. We compare financial performance of investment portfolios with and without fossil fuel companies over the period 1927-2016. Contrary to theoretical expectations, we find that fossil fuel divestment does not seem to impair portfolio performance. These findings can be explained by the fact that, so far, fossil fuel company stocks do not outperform other stocks on a risk-adjusted basis and provide relatively limited diversification benefits. A more pronounced performance impact of divestment can be observed over short time frames and when applied to less diversified market indices.
\end{abstract}

Keywords: Fossil Fuel Divestment; Socially Responsible Investing; Portfolio Performance; Risk-adjusted returns; Market Capitalization; GARCH

JEL codes: A13; D53; G11; Q41

a Department of Economics, Econometrics \& Finance, University of Groningen, PO Box 800, 9700 AV Groningen, The Netherlands

b Centre for Responsible Banking \& Finance, School of Management, University of St. Andrews, The Gateway, North Haugh, St. Andrews, KY16 9RJ Scotland, UK

* Corresponding author. E-mail address: p.j.trinks@rug.nl (Arjan Trinks) Tel: +31 50363 8139 


\section{Introduction}

Divestment campaigns urge investors to sell their stakes in companies that supply coal, oil, or gas. Initiated at US universities, divestment campaigns have gained support from foundations, pension funds, faith-based organizations, governmental organizations, educational institutions, and others. ${ }^{1}$ The aim is to reduce Greenhouse Gas (GHG) emissions by cutting down financial support for and addressing the moral legitimacy of fossil fuel production and its use (Ansar et al., 2013; Ayling and Gunningham, 2017). As of September 2017, \$5.53 trillion of institutions' Assets under Management (AuM) has been committed to divest from at least one type of fossil fuel. ${ }^{2}$

The call for divestment closely relates to the scientific and political debate about the need for global action to avert dangerous anthropogenic climate change (Arbuthnott and Dolter, 2013; Gross, 2015; Van den Bergh and Botzen, 2015). Additionally, it links to debate about the role of finance in the transition to a low-carbon economy (Busch and Hoffmann, 2007; Campiglio, 2016; Scholtens, 2017). The divestment movement contends that investors should do their part by considering the ecological impacts of the activities they finance next to traditional risk-return measures, and therefore withdraw investments in publicly listed coal, oil, and gas companies (Ritchie and Dowlatabadi, 2014).

Conforming to the moral call to divest, however, can be costly and/or problematic for investors (see Ritchie and Dowlatabadi, 2015; Eurosif, 2016). Modern Portfolio Theory (Markowitz, 1952) suggests that constraining an investment portfolio would reduce opportunities for investment-portfolio diversification and consequently would impair financial performance. Fossil fuel companies indeed make up a material part of major benchmark indices. So far, however, the financial implications of fossil fuel divestment have not yet been systematically analyzed. Recently, reports have claimed that divestment comes with substantial costs (Cornell, 2015; Fischell, 2015), while others have suggested that it improves portfolio performance (Heaps et al., 2016). However, these reports apply ad hoc methods and measures, and focus on highly specific samples and study periods, which might explain their opposite conclusions. As divestment may reduce investment returns and thereby affect society at large, it is timely to rigorously study its impact on portfolio performance.

We construct US investment portfolios with and without fossil fuel companies, using industry classifications and the Carbon Underground 200 list. We investigate the differential

\footnotetext{
${ }^{1}$ http://gofossilfree.org/commitments/ (accessed: September 31, 2017).

2 Ibid.
} 
in portfolio risk and performance of fossil-free and unconstrained portfolios by comparing the variance, the Sharpe and Sortino performance ratios, and four-factor adjusted alphas over the period 1927-2016. Our results suggest that fossil fuel divestment has not significantly impaired financial performance of investment portfolios.

Our paper makes three contributions to the academic and societal debate about fossil fuel divestment. First, in the scarce literature on fossil fuel divestment we have not found a comprehensive systematic analysis of the financial dimension of divestment. Our analysis is firmly grounded in Modern Portfolio Theory and covers a broad market over an extensive time horizon. Furthermore, we employ various definitions of fossil fuel divestment and assess the sensitivity of our results to different study periods, investment indices, and model specifications. Secondly, we complement the Socially Responsible Investing (SRI) and screening literature (Humphrey and Tan, 2014; Lobe and Walkshäusl, 2016) by looking into an increasingly relevant application of screening: fossil fuel divestment. Lastly, we contribute to the debate about the implications of improved corporate carbon performance for financial performance. Generally, the literature has found that companies with lower (relative) carbon emissions have a superior financial performance (Busch and Lewandowski, 2017). On the investment side, a recent stream of literature studies the carbon footprint of investment portfolios in an attempt to quantify the investor's exposure to 'carbon risk': the perceived financial risks associated with the transition from high- to low-carbon sources (Andersson et al., 2016; De Jong and Nguyen, 2016). Andersson et al. (2016) find that carbon footprint reductions of up to $50 \%$ are possible while keeping a minimal (neglectable) tracking error. Our study takes the opposite perspective. Given the observed call to divest fossil fuel stocks, we assess financial costs (i.e., underperformance) when answering to it.

This paper proceeds as follows. Section 2 provides a theoretical framework about screening in relation to investment performance, and highlights our contribution to the literature. The methodology and data are described in Sections 3 and 4 respectively. Section 5 presents the results and discusses implications in light of the divestment and screening debate. Section 6 concludes. 


\section{Socially responsible investing and diversification costs}

\subsection{Theoretical framework}

Fossil fuel divestment can be regarded as a specific way of Socially Responsible Investing (SRI), namely exclusion (see Revelli and Viviani, 2015). Through SRI, investors aim to align ethical and financial concerns and consider the 'social damage' that their investment objects might cause (Dam and Scholtens, 2015). A common approach to achieve this is witholding investments in harmful or controversial activities (Eurosif, 2016; Global Sustainable Investment Alliance, 2016). The divestment campaigns frame fossil fuel production as such activity.

Modern Portfolio Theory (Markowitz, 1952; Roy, 1952; Tobin, 1958) implies that any constraint that reduces the investible universe will leave investors with a less efficient portfolio (Galema et al., 2008; Rudd, 1981). Divestment thus may impose an ineffiency, a cost, by increasing ideosyncratic (diversifiable) risk which is not fully compensated by higher returns. We can define the 'diversification costs' following from divestment as the difference in risk-adjusted returns relative to the unconstrained index. Diversification costs are a function of the number of stocks in a portfolio and the correlation between the stock returns (Markowitz, 1952). Hence, the largest diversification costs are expected from the exclusion of a large set of stocks which have a low correlation with other market investments.

Secondly, SRI implies that some investors' utility function may depend on nonfinancial attributes too. The divestment movement, in fact, treats fossil fuel companies as 'sin stocks', i.e. stocks of companies involved in controversial activities that investors commonly stay away from (see also Luo and Balvers, 2017; Hong and Kacperczyk, 2009). Like sin stocks, a reduction of demand for fossil fuel company stocks and excess demand for nonfossil stocks can be expected to reduce prices of the former category (underpricing) and increase prices of the latter (overpricing) (Dam and Scholtens, 2015; Fama and French, 2007; Heinkel et al., 2001). Investors would thus be willing to pay a higher price for non-fossil stocks and would expect a lower return on their investment for a given risk level. When fossil fuel company stocks are systematically screened, this differential should be detectable as positive abnormal risk-adjusted returns (alphas) for fossil fuel portfolios and negative alphas for fossil-free ones. As such, we expect additional outperformance (underperformance) of fossil fuel (fossil-free) portfolios in the period divestment takes place. 
The prevalence of systematic screening of the fossil fuel industry, however, is debatable. Formally, the divestment movement started in 2011 (Ayling and Gunningham, 2017) and so far it seems that a relatively small share of total AuM applies exclusionary screens on the fossil fuel industry. Screening of the fossil fuel industry through other forms of SRI, such as green or thematic investments and best-in-class screening, does not seem to happen systematically on a large scale either. As a result, fossil fuel stocks are unlike some sin stocks, such as tobacco stocks, which have been structurally avoided by investors for long time frames. This suggests that demand for fossil-free company activity might best be taken as given (contrary to Luo and Balvers, 2017), even though the effects from a growing preference for fossil-free investments may become more important in the future.

Still, portfolio diversification is not only constrained because of social norms but because of practical or behavioral reasons as well, suggesting there could be a compensation for idiosyncratic risks (Fu, 2009; Goyal and Santa-Clara, 2003). Accordingly, fossil fuel companies may receive additional returns because of high litigation and reputational risks (cf. Hong and Kacperczyk, 2009) and industry and environmental challenges, such as the need for a radical transition to low- or zero-carbon sources (Ansar et al., 2013; Busch and Hoffmann, 2007). An important consideration in this respect is the appropriate pricing of carbon risk (Andersson et al., 2016; De Jong and Nguyen, 2016; Liesen et al., 2017). For example, a key concern is the risk that future stringent public policy will devalue or 'strand' fossil fuel reserves (Ansar et al., 2013). In fact, some reports advocate fossil fuel divestment based on a prediction of strong declines in the stock prices of fossil fuel companies (see Leaton (2011) and subsequent reports). ${ }^{3}$ Battiston et al. (2017) and Dietz et al. (2016) study the financial implications of various climate policy scenarios and arrive at material impacts.

Lastly, and relatedly, standard asset pricing models may imperfectly capture the risk characteristics of the fossil fuel industry. For instance, the industry's exposure to perceived (ir)responsibility or 'sustainability' risk as well as energy price risk may significantly affect stock returns, while these factors are not being captured by standard asset pricing models (Driesprong et al., 2008; Scholtens, 2014).

\footnotetext{
3 This work builds on findings by Allen et al. (2009) and Meinshausen et al. (2009) that in order to keep the increase in global mean temperature below $2{ }^{\circ} \mathrm{C}$, a commitment ratified in the Paris Agreement, up to $80 \%$ of current proven fossil fuel reserves must be left unused. McGlade and Ekins (2015) highlight the incommensurability of current and planned coal, oil, and gas production in different regions with the $2{ }^{\circ} \mathrm{C}$ limit. However, Griffin et al. (2015) do not find a corresponding strong negative impact of the above publications on US oil and gas companies' stock prices.
} 


\subsection{Empirical literature}

So far, the empirical SRI literature has found little to no negative impact of ethical constraints (screening) on investment portfolio performance (Bello, 2005; Humphrey and Tan, 2014; Lobe and Walkshäusl, 2016; Trinks and Scholtens, 2017). Financial implications of screening might relate not only to the amount or market capitalization of the stocks excluded, but also to the correlation between the returns on the excluded and remaining investment categories, and whether excluded stocks show outperformance due to systematic screening.

We complement the SRI and investment performance literature (see Revelli and Viviani, 2015) by systematically analyzing the risk and return characteristics of portfolios with and without fossil fuel stocks over an extensive time period. Our main interest lies in the size and significance of the diversification costs following from a divestment strategy. To this end, we test for abnormal risk-adjusted return performance of fossil fuel portfolios and fossilfree portfolios. Our approach complements the reports by Cornell (2015), Fischell (2015) and Heaps et al. (2016) by applying a comprehensive systematic analysis grounded in Modern Portfolio Theory, and assessing the robustness of our results to different definitions of fossil fuel divestment, subperiods, stock indices, and model specifications. Our study contributes to the SRI literature which has relied upon much shorter time frames and less comprehensive industry classifications (e.g., Luo and Balvers, 2017), company-level exclusions (Trinks and Scholtens, 2017), or exclusions within particular investment funds (Hoepner and Schopohl, 2016; Ibikunle and Steffen, 2015). We abstract from any dynamic system-wide effects that fossil fuel divestment might have on future stock prices of fossil-fuel and high-carbon companies (cf. Battiston et al., 2017), as well as any additional financial costs that the implementation of divestment might impose, such as selection, transaction, and monitoring costs (see Bessembinder, 2016; cf. Cornell, 2015; Fischell, 2015), which will be highly sensitive to the type, size, and objectives of the investment. 


\section{Methodology}

3.1. Financial performance of the fossil fuel industry and fossil-free portfolios

The diversification costs of fossil-free investment portfolios are evaluated by comparing the risk-adjusted returns on fossil-free portfolios and the unconstrained portfolio. We employ two well-documented measures of portfolio performance, namely the Sharpe ratio and Sortino ratio, and relate returns to risk factors via the Carhart four-factor model. As the two methods cover different portfolio-performance attributes, it is common practice to combine them (Humphrey and Tan, 2014; Lobe and Walkshäusl, 2016). We start by considering returns, total risk, and downside risk of fossil fuel portfolios and fossil-free portfolios.

Reduced diversification resulting from fossil-free investing would first of all be visible in significant differences in total risk (variance) of constrained portfolios compared to unconstrained portfolios. Moreover, in the presence of imperfect investor diversification, portfolio variance would be the appropriate measure to look at, as not only the systematic risk component but idiosyncratic risk as well is to be compensated. Therefore, we employ the Ledoit and Wolf (2011) test for equal variances, which is robust to non-normal and serially correlated return data, next to a standard F-test of equal variances. We then evaluate the reward-to-risk performance of fossil-free portfolios using the Sharpe ratio (Sharpe, 1966) and the Sortino ratio (Sortino and Van der Meer, 1991). The Sharpe ratio makes portfolio performance comparable by measuring the expected return on the portfolio in excess of the risk-free rate per unit of risk:

$$
\operatorname{Sharpe}_{p}=\frac{E\left(R_{p}-R_{f}\right)}{\sigma_{p}}
$$

The numerator, $E\left(R_{p}-R_{f}\right)$ measures the expected return on the portfolio in excess of the risk-free rate. The denumenator, $\sigma_{p}$, is the standard deviation of portfolio returns, which is a measure of total risk. Theoretically, the unconstrained market portfolio has the highest achievable Sharpe ratio (Sharpe, 1964). By comparing the market portfolio with fossil-free portfolios, we assess whether fossil-free investment results in sub-optimal reward-to-risk performance.

The Sortino ratio divides expected excess return by downside risk: 


$$
\operatorname{Sortino~}_{p}=\frac{E\left(R_{p}-R_{f}\right)}{\sqrt{\frac{1}{T} \sum_{t=1}^{T}\left(\operatorname{Min}\left(0, R_{p, t}-R_{f}\right)\right)^{2}}}
$$

Downside risk focuses on the probability of losses (negative excess returns), which might be a better reflection of investors' preference for low levels of 'bad volatility' (Sortino and Van der Meer, 1991). More generally, the Sortino ratio focuses on returns below a Minimal Acceptable Rate of return, $R_{M A R}$, which we take to be the risk-free rate. In both the Sharpe ratio and the Sortino ratio the investor maximizes risk-adjusted return at the portfolio which displays the highest performance ratio. The significance of differences in Sharpe ratios is tested using the robust Ledoit and Wolf (2008) test, as in related studies (Auer, 2016; Lobe and Walkshäusl, 2016), next to the standard Jobson-Korkie (1981) test corrected by Memmel (2003). The Ledoit and Wolf (2008) test is robust against non-normal and serially correlated return data. We use the circular blocks bootstrap procedure with 5,000 resamples, as recommended by Ledoit and Wolf (2008) and used in related literature (Lobe and Walkshäusl, 2016).

Additionally, we evaluate the financial performance of portfolios with and without fossil fuel companies by relating excess returns on each portfolio to well-documented (systematic) risk factors. In line with related studies (Humphrey and Tan, 2014; Lobe and Walkshäusl, 2016), we estimate the Carhart (1997) four-factor model:

$R_{p, t}-R_{f, t}=\alpha_{p}+\beta_{p, m}\left(R_{m, t}-R_{f, t}\right)+\beta_{p, S M B} S M B_{t}+\beta_{p, H M L} H M L_{t}+\beta_{p, W M L} W M L_{t}+\varepsilon_{p, t}$ (3)

The Carhart model relates the excess returns on an investment portfolio $p$ in month $t$, which consists of stocks weighted by their market capitalization in the previous month, to four common determinants of risk (Carhart, 1997). $R_{m, t}-R_{f, t}$, the market risk premium, is the return on a market capitalization-weighted market portfolio in excess of the risk-free rate. $S M B_{t}$ (Small minus Big) is the return on a portfolio long in small cap stocks and short in large caps. The $H M L_{t}$ (High minus Low) factor, in a similar fashion, measures the return differential between high and low book-to-market stocks. $W M L_{t}$ (Winners minus Losers) represents the return on a portfolio long in stocks with the highest returns and short in those with the worst performance in previous 12 months. $\alpha_{p}$ represents the coefficient of interest, 
namely the portfolio’s abnormal return performance when controlling for the above four risk factors.

Since divestment implications will depend on the characteristics of fossil fuel stocks (see Section 2.2), we will first look into the performance of fossil fuel portfolios (Section 5.1) before turning to the impact of fossil fuel divestment (Section 5.2). The impact of fossil fuel divestment on asset prices is tested using the long-short (zero-investment) approach (see Hong and Kacperczyk, 2009; Lobe and Walkshäusl, 2016), regressing the returns on a hypothetical portfolio with a long (positive) position in the fossil fuel company portfolio (a 'socially controversial' or sinful portfolio) and a corresponding short (negative) position in the fossil-free portfolio (a ‘socially responsible’ portfolio) on the four Carhart factors (Eq. 3). The resulting alphas in these regressions provide a clean measure of the risk-adjusted return performance of investments in the fossil fuel industry when benchmarked against all remaining investment categories. Next, we test the performance of fossil-free investment portfolios by regressing their excess returns on the Carhart factors (Eq. 3). BECAUSE

Finally, we assess the robustness of our results. Diversification costs, the reduction in risk-adjusted returns due to a divestment strategy, may vary over time, as do our model's parameters. Therefore, we test whether the effect of divestment is more pronounced and negative in the period after the first divestment campaigns in 2011, and cut our study period into various subperiods of $30,15,10$, and 5 years. Analysis of subperiods also accounts for the differences in investment horizons. In addition, since investors in practice often rely on restricted market indices, we rerun our analysis applying fossil-fuel screens to the S\&P 500 and FTSE 100 indices. Finally, we address volatility clustering directly by modeling it as a GARCH(1,1) process.

Note that diversification costs may result from a reduced investment universe (number of stocks) and portfolio composition (type of stocks). If there would be significant diversification costs, the two effects could be disentangled using the approach by Humphrey and Tan (2014), which simulates portfolios of equal size and as such quantifies the portfolio composition effect. However, such analysis is beyond the scope of this paper.

\section{Data}

We construct portfolios with and without publicly listed fossil fuel companies. We extract data on all listed and delisted US common stocks from the Center for Research in 
Security Prices (CRSP). Fossil fuel stocks are identified using Standard Industry Classification (SIC) codes (cf. Fama and French, 1997). ${ }^{4}$ Using industry classifications is common practice in investment management and academic research (Hong and Kacperczyk, 2009; Humphrey and Tan, 2014). We apply two different approaches to identify fossil fuel companies (see Table 1 for definitions). First, we follow the general approach of the divestment movement and focus on companies that are closely linked to the supply (production) of fossil fuels (see, e.g., Ansar et al., 2013). We contend that this industry definition is sufficiently broad to capture differences in focus among divestment practitioners. Notably, divestment intuitively calls for the exclusion of energy majors, but these are often grouped in petroleum refining (SIC 291) and as such would have been ignored when using a narrower industry definition (cf. Fama and French, 1997; Luo and Balvers, 2017). Moreover, a broad definition of divestment serves as an 'upper bound' to the potential impact of divestment, as the impact of excluding less stocks (based on a narrower definition of divestment) would be smaller. ${ }^{5}$

As a second definition, we consider the companies included in the Carbon Underground 200 (CU200), which is a list composed by Fossil Free Indexes LLC of the 100 largest coal companies and 100 largest oil and gas companies based on reported reserves. The list is often employed by advocates of divestment as a useful starting point ${ }^{6}$ as it provides a straightforward method to identify the potential carbon content of one's investments (see Ritchie and Dowlatabadi, 2014). The CU200 sample is constructed using the CU200 list as of July $2016^{7}$ and identification is done through ISIN numbers (using ORBIS) and company names (manually). Note that the CU200 sample has a limited number of return observations because there are no CU200 oil and gas companies before 08/1955 and no CU200 coal companies before 02/1949 and at other early time frames. We do not explicitly consider other SRI strategies which can be used instead or alongside divestment. This is addressed by Schwarz (2015), among others. One approach would be Divest-Invest, which replaces fossil fuel investments by low- or zero-carbon ones. Investors could use the recently developed

\footnotetext{
${ }^{4}$ Our results are robust to complementing SIC codes with North American Industry Classication System (NAICS) codes. We use NAICS 2121, 213113, and 333131 for coal stocks, and NAICS 211, 213111, 213112, 2212, 23712, 32411, 333132, and 486 for oil and gas company stocks. NAICS codes are available in CRSP only from 2004 onwards and do not contain many additional stocks.

${ }^{5}$ As a sensitivity analysis, we also apply a narrower definition of divestment, focusing on coal mining (SIC 12) and oil and gas extraction (SIC 13). Results, which are qualitatively similar, are available upon request at the corresponding author.

${ }^{6}$ http://gofossilfree.org/top-200/ (accessed: August 8, 2016).

7 We thank Carbon Tracker Initiative for making this information publicly available at http://fossilfreeindexes.com/research/the-carbon-underground/ (accessed: August 2, 2016).
} 
Carbon Clean 200 (CC200), a list of the 200 largest stocks based on green energy revenues (Heaps et al., 2016), as a natural opposite of the CU200. Note, however, that our main analysis fully covers CC200 stocks and, by construction, in fossil-free portfolios, weights of CC200 stocks and other remaining non-fossil fuel stocks are increased proportionally to their market capitalization. Our analysis thus aligns with the fact that divestment moves capital away from the fossil fuel industry to other sectors (Ritchie and Dowlatabadi, 2014).

For each of the two identification approaches (using the industry definition as well as the CU200 list) we construct three fossil fuel portfolios, consisting of all companies involved in coal, oil and gas, or all fossil fuels. Hence, we end up with six (2x3) fossil fuel company portfolios. Correspondingly, we construct six fossil-free portfolios by discarding from the CRSP market portfolio all stocks in the respective fossil fuel portfolios. Portfolio returns are monthly market capitalization-weighted returns. From CRSP we obtain monthly total returns (i.e., including dividends), closing stock prices, and shares outstanding for NYSE, Amex, and Nasdaq stocks over the period 1927-2016. Hence, we have 1,080 monthly return observations for each fossil-free portfolio. We follow the literature (Lobe and Walkshäusl, 2016; Luo and Balvers, 2017) by focusing on companies with CRSP share codes of 10 or 11 and excluding companies with one-digit SIC codes of 6, which belong to the financial services industry. US factor data are obtained from CRSP. Note that, by construction, the unconstrained market portfolio is identical to the Fama-French US market factor.

Table 1 shows the definition and the number of stocks in the market portfolio, the six fossil fuel portfolios, and the six corresponding fossil-free portfolios. Companies involved in fossil fuel supply (SIC industry definition) comprise about 7\% of the number of stocks in the market portfolio. Note that the number of stocks in each portfolio at a particular point in time will be lower. For instance, at December 2016, the market portfolio contains 3,041 stocks, of which 164 fossil fuel stocks based on the SIC industry definition. Table 1 suggests that fossilfuel screening, with the exception of screening for coal, could considerably reduce the number of investible assets. 


\begin{tabular}{|c|c|c|c|}
\hline Source & Portfolio label & Definition & \#stocks \\
\hline CRSP & Market & $\begin{array}{l}\text { All stocks listed on NYSE, Amex, and Nasdaq excluding those with CRSP share codes } \\
\text { other than } 10 \text { or } 11 \text { and those belonging to the financial services industry. }\end{array}$ & 20,496 \\
\hline \multicolumn{4}{|c|}{ Fossil fuel portfolios } \\
\hline \multirow[t]{3}{*}{ SIC } & Coal & SIC 12 (coal mining), 3532 (mining machinery) & 84 \\
\hline & Oil and gas & $\begin{array}{l}\text { SIC } 13 \text { (oil and gas extraction), } 291 \text { (petroleum refining), } 3533 \text { (oil and gas field } \\
\text { machinery and equipment), } 46 \text { (pipelines, except natural gas), } 492 \text { (gas production and } \\
\text { distribution) }\end{array}$ & 1,379 \\
\hline & All fossil fuels & SIC Coal U Oil and gas & 1,455 \\
\hline \multirow[t]{3}{*}{ CU200 } & Coal & CU200 Coal list & 13 \\
\hline & Oil and gas & CU200 Oil and gas list & 31 \\
\hline & All fossil fuels & CU200 Coal U Oil and gas & 43 \\
\hline \multicolumn{4}{|c|}{ Fossil-free portfolios } \\
\hline \multirow[t]{3}{*}{ SIC } & Coal & CRSP market portfolio excluding SIC Coal stocks & 20,412 \\
\hline & Oil and gas & CRSP market portfolio excluding SIC Oil and gas stocks & 19,117 \\
\hline & All fossil fuels & CRSP market portfolio excluding SIC All fossil fuels stocks & 19,041 \\
\hline \multirow[t]{3}{*}{ CU200 } & Coal & CRSP market portfolio excluding CU200 Coal stocks & 20,483 \\
\hline & Oil and gas & CRSP market portfolio excluding CU200 Oil and gas stocks & 20,465 \\
\hline & All fossil fuels & CRSP market portfolio excluding CU200 All fossil fuels stocks & 20,453 \\
\hline
\end{tabular}

\section{Results and discussion}

In this section, we first investigate the financial performance characteristics of the fossil fuel industry. We then report our findings for the effects of applying fossil fuel industry screens and discuss the implications for the divestment debate. Finally, we test and discuss the robustness of our findings.

\subsection{Performance of fossil fuel investments}

Table 2 presents the descriptive statistics and portfolio performance measures for the portfolios with and without fossil fuel stocks. We find higher returns and higher risk for fossil fuel stocks, which is consistent with the hypothesized higher industry risk (Driesprong et al., 2008; Ansar et al., 2013). For instance, excess returns on a portfolio consisting of coal, oil and gas company stocks (SIC industry definition) have averaged $0.73 \%$ per month at a total risk 
(standard deviation) of 5.92\%, whereas the market portfolio has generated average excess returns of $0.65 \%$ at a lower total risk of $5.35 \%$.

\begin{tabular}{|c|c|c|c|c|c|c|c|c|c|c|}
\hline & & $\mathrm{N}$ & Mean & Median & StDev & $\mathrm{DR}$ & Sharpe & Sortino & $\Delta$ Var & $\Delta$ Sharpe \\
\hline CRSP & Market portfolio & 1,080 & $0.65 \%$ & $0.92 \%$ & $5.35 \%$ & $3.54 \%$ & 0.1211 & 0.1827 & - & - \\
\hline \multicolumn{11}{|c|}{ Fossil fuel portfolios } \\
\hline \multirow[t]{3}{*}{ SIC } & Coal & 1,080 & $0.61 \%$ & $0.28 \%$ & $10.17 \%$ & $6.05 \%$ & 0.0601 & 0.1011 & - & - \\
\hline & Oil and gas & 1,080 & $0.73 \%$ & $0.67 \%$ & $5.91 \%$ & $3.77 \%$ & 0.1241 & 0.1948 & - & - \\
\hline & All fossil fuels & 1,080 & $0.73 \%$ & $0.69 \%$ & $5.92 \%$ & $3.78 \%$ & 0.1229 & 0.1926 & - & - \\
\hline \multirow[t]{3}{*}{ CU200 } & Coal & 750 & $0.74 \%$ & $0.38 \%$ & $8.39 \%$ & $5.03 \%$ & 0.0880 & 0.1467 & - & - \\
\hline & Oil and gas & 737 & $0.90 \%$ & $0.70 \%$ & $6.69 \%$ & $3.88 \%$ & 0.1345 & 0.2317 & - & - \\
\hline & All fossil fuels & 815 & $0.89 \%$ & $0.77 \%$ & $6.92 \%$ & $3.99 \%$ & 0.1284 & 0.2224 & - & - \\
\hline \multicolumn{11}{|c|}{ Fossil-free portfolios } \\
\hline \multirow[t]{3}{*}{ SIC } & Market excl. Coal & 1,080 & $0.65 \%$ & $0.92 \%$ & $5.34 \%$ & $3.54 \%$ & 0.1213 & 0.1830 & $-0.0004 \%$ & 0.0002 \\
\hline & Market excl. Oil and gas & 1,080 & $0.64 \%$ & $1.04 \%$ & $5.45 \%$ & $3.61 \%$ & 0.1182 & 0.1785 & $0.0116 \%$ & -0.0029 \\
\hline & Market excl. All fossil fuels & 1,080 & $0.65 \%$ & $1.03 \%$ & $5.45 \%$ & $3.61 \%$ & 0.1184 & 0.1789 & $0.0111 \%$ & -0.0026 \\
\hline \multirow[t]{3}{*}{ CU200 } & Market excl. Coal & 1,080 & $0.65 \%$ & $0.93 \%$ & $5.35 \%$ & $3.54 \%$ & 0.1211 & 0.1827 & $-0.0000 \%$ & 0.0000 \\
\hline & Market excl. Oil and gas & 1,080 & $0.65 \%$ & $0.95 \%$ & $5.36 \%$ & $3.55 \%$ & 0.1206 & 0.1818 & $0.0011 \%$ & -0.0005 \\
\hline & Market excl. All fossil fuels & 1,080 & $0.65 \%$ & $0.95 \%$ & $5.36 \%$ & $3.55 \%$ & 0.1206 & 0.1818 & $0.0011 \%$ & -0.0005 \\
\hline
\end{tabular}

This table presents the number of observations (N), mean, median, standard deviation, and downside risk (DR) of monthly excess returns on the fossil fuel and fossil-free portfolios, as well as their Sharpe and Sortino ratios over the period 01/1927-12/2016. Downside risk is the standard deviation of negative excess returns. The Sharpe ratio is the excess return divided by the standard deviation of portfolio returns. The Sortino ratio divides expected excess return by downside risk. The CRSP market portfolio includes all stocks listed on NYSE, Amex, and Nasdaq excluding those with CRSP share codes other than 10 or 11 and those belonging to the financial services industry. The SIC industry definition includes SIC 12, 3532 (coal) and SIC 13, 291, 3533, 46, and 492 (oil and gas). CU200 is the July 2016 Carbon Underground 200 list from Fossil Free Indexes LLC of the 100 largest coal companies and 100 largest oil and gas companies based on reported reserves (http://gofossilfree.org/top-200/). $\Delta$ Var is the difference between each portfolio's variance and the variance of the CRSP Market portfolio. $* * *$ $\mathrm{p}<0.01,{ }^{* *} \mathrm{p}<0.05,{ }^{*} \mathrm{p}<0.10$, with ${ }^{\mathrm{F}}$ denoting the F-test for equality of variances and ${ }^{\mathrm{LW}}$ the robust Ledoit-Wolf (2011) alternative using the studentized time series bootstrapping procedure with 5,000 resamples. $\Delta$ Sharpe is the difference between each portfolio’s Sharpe ratio and that of the CRSP Market portfolio. JK denotes the Jobson-Korkie (1981) test of equal Sharpe ratios and ${ }^{\mathrm{LW}}$ the robust Ledoit-Wolf (2008) alternative using the studentized time series bootstrapping procedure with 5,000 resamples.

To evaluate the performance of the fossil fuel industry, we control for welldocumented risk factors through the Carhart four-factor model (Eq. 3). Table 3 shows that over the 1927-2016 period fossil fuel portfolios have generated slightly positive but insignificant alphas when benchmarked against fossil-free portfolios. This demonstrates the substantial systematic risk associated with investments in the fossil fuel industry (in line with Driesprong et al. (2008) and related studies), which offsets the above-market returns observed in this industry. In particular, the significant loadings on the Market, SMB, and HML risk factors indicate that the relatively high average excess returns on fossil fuel stocks can largely be explained as a compensation for their significant exposure to systematic risk factors. As shown by the coefficients on the SMB and HML factors in Table 3, fossil fuel stocks are mostly largecap value stocks, while fossil-free portfolios tend to be slightly smaller and more growth-oriented. 
Table 3: Risk-adjusted return performance of fossil fuel portfolios (Carhart model, 1927-2016)

\begin{tabular}{|c|c|c|c|c|c|c|}
\hline & \multicolumn{3}{|l|}{ SIC } & \multicolumn{3}{|l|}{ CU200 } \\
\hline Portfolio: & Coal & Oil and gas & All fossil fuels & Coal & Oil and gas & All fossil fuels \\
\hline MktRf & $\begin{array}{l}0.0675 \\
(0.0597)\end{array}$ & $\begin{array}{l}-0.1053 * * \\
(0.0473)\end{array}$ & $\begin{array}{l}-0.1011^{* *} \\
(0.0472)\end{array}$ & $\begin{array}{l}-0.0476 \\
(0.0973)\end{array}$ & $\begin{array}{l}-0.0295 \\
(0.0737)\end{array}$ & $\begin{array}{l}0.0026 \\
(0.0671)\end{array}$ \\
\hline SMB & $\begin{array}{l}0.4476 * * * \\
(0.1203)\end{array}$ & $\begin{array}{l}-0.2372^{* * *} \\
(0.0543)\end{array}$ & $\begin{array}{l}-0.2288 * * * \\
(0.0545)\end{array}$ & $\begin{array}{l}-0.0518 \\
(0.1146)\end{array}$ & $\begin{array}{l}-0.2777 * * * \\
(0.1026)\end{array}$ & $\begin{array}{l}-0.2540 * * * \\
(0.0933)\end{array}$ \\
\hline HML & $\begin{array}{l}0.6614 * * * \\
(0.1237)\end{array}$ & $\begin{array}{l}0.2766^{* * *} \\
(0.0704)\end{array}$ & $\begin{array}{l}0.2847 * * * \\
(0.0694)\end{array}$ & $\begin{array}{l}0.5210 * * * \\
(0.1901)\end{array}$ & $\begin{array}{l}0.5447 * * * \\
(0.1414)\end{array}$ & $\begin{array}{l}0.6426 * * * \\
(0.1376)\end{array}$ \\
\hline WML & $\begin{array}{l}-0.1573 \\
(0.1086)\end{array}$ & $\begin{array}{l}0.1036^{*} \\
(0.0612)\end{array}$ & $\begin{array}{l}0.1007^{*} \\
(0.0603)\end{array}$ & $\begin{array}{l}-0.0281 \\
(0.1011)\end{array}$ & $\begin{array}{l}0.0191 \\
(0.0871)\end{array}$ & $\begin{array}{l}0.0090 \\
(0.0807)\end{array}$ \\
\hline Alpha & $\begin{array}{l}-0.0034 \\
(0.0023)\end{array}$ & $\begin{array}{l}0.0003 \\
(0.0012)\end{array}$ & $\begin{array}{l}0.0002 \\
(0.0012)\end{array}$ & $\begin{array}{l}-0.0006 \\
(0.0028)\end{array}$ & $\begin{array}{l}0.0024 \\
(0.0019)\end{array}$ & $\begin{array}{l}0.0006 \\
(0.0020)\end{array}$ \\
\hline $\begin{array}{l}\mathrm{N} \\
\mathrm{R}^{2}\end{array}$ & 1,080 & 1,080 & 1,080 & 750 & 737 & 815 \\
\hline $\mathrm{R}^{2}$ & 0.1994 & 0.1019 & 0.1002 & 0.0411 & 0.1022 & 0.1091 \\
\hline
\end{tabular}

This table reports the results from regressing the excess returns on a zero-investment portfolio with a long position in the fossil fuel portfolios and a corresponding short position in the CRSP market portfolio excluding fossil fuels on the Carhart (1997) US factors using OLS. The SIC industry definition includes SIC 12, 3532 (coal) and SIC 13, 291, 3533, 46, and 492 (oil and gas). CU200 is the July 2016 Carbon Underground 200 list from Fossil Free Indexes LLC of the 100 largest coal companies and 100 largest oil and gas companies based on reported reserves (http://gofossilfree.org/top-200/). Alpha is the intercept, indicating relative out- or underperformance. MktRf, SMB, HML, and WML are the coefficients on the Market, Size, Book-to-Market, and Momentum factors respectively. Newey-West (1987) heteroskedasticity and autocorrelation consistent (HAC) standard errors are in parentheses. $* * * \mathrm{p}<0.01,{ }^{* *} \mathrm{p}<0.05,{ }^{*} \mathrm{p}<0.10$.

Clearly, the fossil fuel industry is unlike other controversial industries, such as alcohol, tobacco, and gambling, which do show significant outperformance (Hong and Kacperczyk, 2009; Trinks and Scholtens, 2017). It thus seems that divestment behavior has to become more prevalent in order to have any significant pricing impacts (cf. Heinkel et al., 2011), such that there will be outperformance of fossil fuel stocks. Furthermore, as the loading on the Market factor in Table 3 is close to 0 , there is only a small difference between the beta of the fossil fuel portfolio and the rest of the market. This means that fossil fuel stocks are more or less substitutes for the market index (which has a beta of 1) and as such provide limited diversification benefits. By contrast, betas of alcohol, tobacco, and gambling stocks are as low as 0.4 (see Trinks and Scholtens, 2017). Thirdly, note that fossil fuel divestment currently targets only the fossil fuel production industry, which means that divestment will induce a limited sector bias. However, in the future investors might expand the scope of fossil fuel divestment to better capture the interdependence of fossil fuel supply and economic activity (cf. Ritchie and Dowlatabadi, 2014). For instance, power generation and the use of fossil fuels by manufacturing industries might be accounted for. To this end, investors might decide to consider other lists, such as the 'filthy fifteen' of the largest and most carbon-intensive US coal mining companies and coal-fired utilities 
(https://fossilfreefunds.org/filthy-15/) or the 90 US 'carbon majors' identified by Heede (2014) to be responsible for two-thirds of historical GHG emissions. Applying a broader definition of fossil fuel divestment could induce a larger sector bias in investment portfolios. Moreover, in terms of the number of stocks and market capitalization, the fossil fuel industry represents a relatively large part of the market portfolio (up to 7\% of the market capitalization of the US market and about 25\% of the FTSE 100 index). For comparison, the frequently studied alcohol, tobacco, and gambling sectors comprise about $2 \%$ of the market (Trinks and Scholtens, 2017).

From a pure financial perspective, however, the decision to divest should not be based on the performance of fossil fuel stocks in isolation, but rather it should be looked at how divesting fossil fuel stocks impacts the total portfolio of the investor. This is what we will do in the next subsection.

\subsection{Performance of fossil-free investments}

We now turn to the impact of divesting fossil fuel stocks on investment portfolios. To this end, we compare performance of the unconstrained market portfolio with that of portfolios which exclude fossil fuel company stocks from the market portfolio. Figure 1 shows the year-average percentage share of fossil fuel stocks in the market portfolio. While on average the effects of screening are modest, there is considerable variation in the share the fossil fuel industry takes in the market portfolio in our sample period. Higher percentage shares, as witnessed in the 1980s for instance, could mean larger diversification costs related to a divestment strategy. This is relevant to the divestment debate, as implications of divestment might become more or less pronounced in future periods when the market share of fossil fuel stocks could change. 
Figure 1: Year-average percentage share of fossil fuel companies in the market portfolio

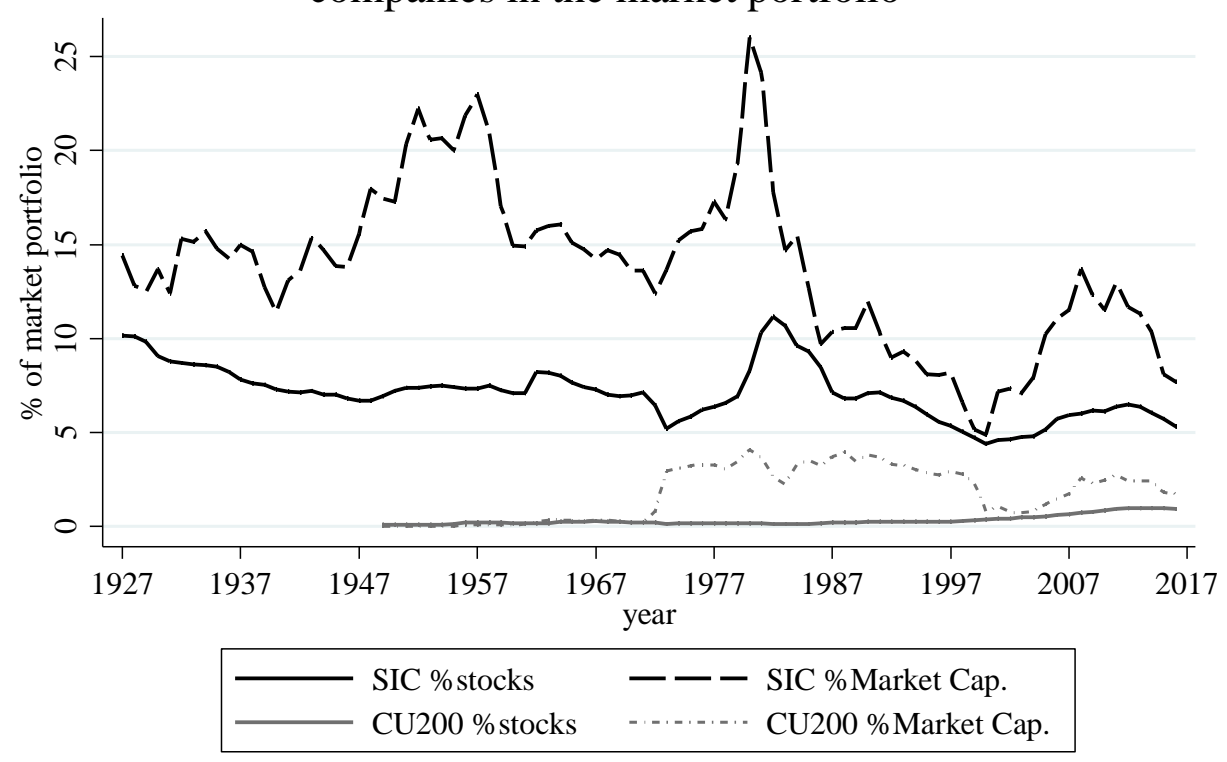

As shown in the last two columns of Table 2, there tends to be some additional total risk (variance) and a lower Sharpe ratio of fossil-free portfolios compared to the unconstrained market portfolio. This finding complements the portfolio performance literature by showing that portfolio diversification benefits may still increase in portfolios which already include a large number of stocks (cf. Evans and Archer, 1968; Statman, 1987) by expanding the activity set covered by the portfolio. However, the variance and Sharpe ratio differential is not significant. Results for Sortino ratios are qualitatively similar. Hence, there does not seem to be a significant reduction in diversification opportunities following from a divestment strategy. Furthermore, as the fossil fuel industry is characterized by substantial input price risk (Driesprong et al., 2008), we might expect that excluding fossil fuels from the investment portfolio would limit downside risk. Interestingly, however, we find downside risk to be slightly higher and Sortino ratios to be slightly lower for fossil-free portfolios. This contrasts with findings by Nofsinger and Varma (2014) who find that socially responsible investments display lower downside risk.

To further investigate the performance impact of divestment, we compare the fourfactor risk-adjusted return performance of fossil-free portfolios relative to the unconstrained market portfolio (Table 4). We generally find no evidence of significant abnormal riskadjusted returns on fossil-free portfolios over the period 1927-2016, as indicated by the insignificant alphas. Only the portfolio that excludes coal stocks based on SIC codes shows a 
significant outperformance; however, the effect size is quite small (around 0.001\% monthly). The absence of a material effect can be explained by the fact that fossil fuel stocks provide relatively limited portfolio diversification benefits (see Section 5.1), and coal stocks make up only $0.04-0.75 \%$ of the total number of stocks and $0.08-0.24 \%$ of the total market capitalization of the market portfolio. Note also that the share of fossil fuel stocks in the market portfolio has declined substantially in more recent time frames (see Figure 1).

Table 4: Risk-adjusted return performance of fossil-free portfolios (Carhart model, 1927-2016)

\begin{tabular}{|c|c|c|c|c|c|c|}
\hline \multicolumn{4}{|c|}{ SIC } & \multicolumn{3}{|l|}{ CU200 } \\
\hline Portfolio: & Coal & Oil and gas & All fossil fuels & Coal & Oil and gas & All fossil fuels \\
\hline MktRf & $\begin{array}{l}0.9996 * * * \\
(0.0002)\end{array}$ & $\begin{array}{l}1.0047 * * * \\
(0.0078)\end{array}$ & $\begin{array}{l}1.0042 * * * \\
(0.0079)\end{array}$ & $\begin{array}{l}0.9999 * * * \\
(0.0001)\end{array}$ & $\begin{array}{l}1.0016 * * * \\
(0.0008)\end{array}$ & $\begin{array}{l}1.0015 * * * \\
(0.0009)\end{array}$ \\
\hline SMB & $\begin{array}{l}-0.0007^{* * *} \\
(0.0002)\end{array}$ & $\begin{array}{l}0.0320 * * * \\
(0.0071)\end{array}$ & $\begin{array}{l}0.0312 * * * \\
(0.0072)\end{array}$ & $\begin{array}{l}0.0001 \\
(0.0001)\end{array}$ & $\begin{array}{l}0.0037 * * * \\
(0.0011)\end{array}$ & $\begin{array}{l}0.0038 * * * \\
(0.0011)\end{array}$ \\
\hline HML & $\begin{array}{l}-0.0013^{* * *} \\
(0.0004)\end{array}$ & $\begin{array}{l}-0.0226 * * \\
(0.0090)\end{array}$ & $\begin{array}{l}-0.0241^{* * *} \\
(0.0090)\end{array}$ & $\begin{array}{l}-0.0001 \\
(0.0001)\end{array}$ & $\begin{array}{l}-0.0051^{* * *} \\
(0.0012)\end{array}$ & $\begin{array}{l}-0.0053 * * * \\
(0.0013)\end{array}$ \\
\hline WML & $\begin{array}{l}0.0003 \\
(0.0003)\end{array}$ & $\begin{array}{l}-0.0216^{* *} \\
(0.0098)\end{array}$ & $\begin{array}{l}-0.0213^{* *} \\
(0.0098)\end{array}$ & $\begin{array}{l}-0.0002 \\
(0.0001)\end{array}$ & $\begin{array}{l}-0.0007 \\
(0.0011)\end{array}$ & $\begin{array}{l}-0.0009 \\
(0.0011)\end{array}$ \\
\hline Alpha & $\begin{array}{l}0.0000 * * \\
(0.0000)\end{array}$ & $\begin{array}{l}0.0001 \\
(0.0002)\end{array}$ & $\begin{array}{l}0.0001 \\
(0.0002)\end{array}$ & $\begin{array}{l}0.0000 \\
(0.0000)\end{array}$ & $\begin{array}{l}-0.0000 \\
(0.0000)\end{array}$ & $\begin{array}{l}-0.0000 \\
(0.0000)\end{array}$ \\
\hline $\begin{array}{l}\mathrm{N} \\
\mathrm{R}^{2}\end{array}$ & $\begin{array}{l}1,080 \\
1.0000\end{array}$ & $\begin{array}{l}1,080 \\
0.9889\end{array}$ & $\begin{array}{l}1,080 \\
0.9887\end{array}$ & $\begin{array}{l}1,080 \\
1.0000\end{array}$ & $\begin{array}{l}1,080 \\
0.9997\end{array}$ & $\begin{array}{l}1,080 \\
0.9997\end{array}$ \\
\hline
\end{tabular}

This table reports the results from regressing the excess returns on the zero-investment portfolio with a long position in the fossil-free portfolio and a short position in the unconstrained market portfolio on the Carhart (1997) US factors using OLS. The SIC industry definition includes SIC 12, 3532 (coal) and SIC 13, 291, 3533, 46, and 492 (oil and gas). CU200 is the July 2016 Carbon Underground 200 list from Fossil Free Indexes LLC of the 100 largest coal companies and 100 largest oil and gas companies based on reported reserves (http://gofossilfree.org/top-200/). Alpha is the intercept, indicating relative out- or underperformance. MktRf, SMB, HML, and WML are the coefficients on the Market, Size, Book-to-Market, and Momentum factors respectively. Newey-West (1987) heteroskedasticity and autocorrelation consistent (HAC) standard errors are in parentheses. *** $\mathrm{p}<0.01,{ }^{* *} \mathrm{p}<0.05, * \mathrm{p}<0.10$.

Our finding of no performance differential between fossil-free and unconstrained portfolios is in line with the portfolio literature on the effects of SRI and screening (Andersson et al., 2016; Bello, 2005; Humphrey and Tan, 2014; Lobe and Walkshäusl, 2016). Furthermore, our analysis suggests that it is important that conclusions about the implications of fossil fuel divestment for portfolio performance be based on a comprehensive sample and study period, as opposed to cherry-picked historical subperiods and indices (cf. Cornell, 2015; Fischell, 2015; Heaps et al., 2016).

Interestingly, we find that in the regression of the fossil-free portfolio returns on the Carhart factors nearly all variation in the returns on the fossil-free portfolios is captured by 
the market factor. The R-squared in these regressions is very close to one for coal-free portfolios, while it is slightly lower for oil and gas-free portfolios. This corresponds to the findings by Andersson et al. (2016) that investors may substantially reduce the carbon footprint of portfolios by divesting the fossil fuel industry, coal stocks in particular, at a minimal tracking error.

\subsection{Sensitivity analyses}

To test the robustness of our main results we consider the effect of divestment in the period following the first divestment campaigns, other subperiods, the S\&P 500 and the FTSE 100 indices, and applying a GARCH(1,1) regression specification. All underlying results tables are available upon request at the corresponding author.

\section{Impact of divestment campaigns (2011-2016)}

First, we test whether the effect of divestment on portfolio performance has been more pronounced in the period following the first divestment campaigns. Wide-spread divestment of fossil fuel company stocks would lead fossil fuel portfolios to outperform fossil-free ones (Dam and Scholtens, 2015; Heinkel et al., 2001). To find out, we extend regression model (Eq. 3) with a time dummy, Divestment ${ }_{t}$, which takes on the value 1 in the period from the start of the first divestment campaigns (2011-2016) and 0 for the period before (1927-2010).

Contrary to our expectations, we find a significant underperformance of coal and CU200 stocks and outperformance of coal-free portfolios during the period since the start of the first divestment campaigns (2011-2016), as indicated by the loadings on the Divestment dummy in Table A.1 and Table A.2. However, it should be noted that this underperformance is only observed for a relatively short time period that coincides with significant declines in fossil fuel prices. We employ two additional tests (not reported) to further investigate our findings. First, we include Western Texas Intermediate (WTI) spot Cushing price (\$/barrel) $\log$ returns as an additional pricing factor in our regressions (in line with Driesprong et al., 2008; Scholtens and Yurtsever, 2012). As a robustness check, we use the WTI three-month futures price as an alternative oil price measure. When we account for movements in the oil price, negative alphas on fossil fuel stocks disappear. This suggests that the underperformance of fossil fuel portfolios during 2011-2016 can be attributed mainly to the negative oil price 
shock in that time period (cf. Scholtens and Yurtsever, 2012). Secondly, including a time dummy in Eq. 3 assumes that divestment has a sudden impact on stock prices, whereas demand effects (Dam and Scholtens, 2015; Heinkel et al., 2001) may materialize gradually as more and more investors apply divestment while market equilibrium has yet to be established. We therefore compare Dividend-Price (D/P) ratios of fossil fuel portfolios with those of the market portfolio in the period 2011-2016. We obtain annual D/P ratios from CRSP total return data including and excluding dividends, following Cochrane (2008, p.1541). We do not find a substantial rise in D/P ratios of our fossil fuel portfolios relative to those of the market. This suggests that the only explanation for the absence of outperformance of fossil fuel investments during 2011-2016 is that the market for divestment is not (currently) large enough to induce substantial price effects, and market equilibrium has yet to be reached. In line with Lobe and Walkshäusl (2016), our findings can thus best be explained by a lack of persistent influence of SRI investors on asset prices.

\section{Subperiods}

To assess the stability of our results over time, we cut our study period into various subperiods of 30,15, 10, and 5 years. Table A.5 in the Appendix lists the performance of portfolios with and without fossil fuels (SIC broad definition) over 15-year time frames. Results for other time frames and portfolios are qualitatively similar and available upon request from the corresponding author. The performance (alpha) of the fossil fuel industry clearly varies over time, while there is no clear out- or underperformance of fossil-free portfolios. On average Sharpe ratios are lower for divested portfolios. Interestingly, we observe positive alphas for fossil fuel portfolios in the most recent 15 years. This underlines our finding that the period of underperformance following recent divestment campaigns is an exceptional case which is preceded by a period of good fortune for fossil fuel investments.

In line with our expectations, we further observe that the impact of divestment relates to the proportion of stocks excluded during specific time frames. With the decline in the share of the fossil fuel industry in the market portfolio in the past 30 years has come a relatively low impact of divestment on Sharpe ratios. The outperformance of fossil-free investments in the 1980s illustrates the effects from the type and proportion of the stocks excluded. The outperformance in this period corresponds with the fossil fuel industry's strong underperformance, the shock in its beta, and its substantial share in the market. 
In practice, investors often rely on restricted market indices which imperfectly reflect the market portfolio. Most SRI funds use the S\&P 500 as their benchmark (Humphrey and Tan, 2014). In the divestment discussion, the FTSE 100 is often considered next to the S\&P 500, due to its high share of fossil energy companies (Leaton, 2011). For the S\&P 500, we obtain historical constituents data from Compustat (1964-2016) and discard all stocks which are in each of our six fossil fuel samples. This dataset is then merged with CRSP total return and market value data (as in Humphrey and Tan (2014)). For the FTSE 100, we retrieve historical constituents from Datastream (1996-2016) and combine these with industry classifications by SIC (see Table 1) and NACE $^{8}$ using ORBIS. We use the US factors from Kenneth French's website in the S\&P 500 regressions and the UK factors (Gregory et al., 2013) ${ }^{9}$ in the FTSE 100 regressions.

Results for the divested S\&P 500 (Tables A.5-A.7) and FTSE 100 (Table A.8-A.10), show that, consistent with our expectations, the impact of divestment is more pronounced negative for portfolios that are less diversified, particularly for the FTSE 100. Figure A.1 shows that about twice the proportion of stocks is excluded from the FTSE 100 (about 10\% of the stocks with a market capitalization of $25 \%$ in the index). For the S\&P 500, we find results very similar to our main analysis, with divested portfolios generally showing Sharpe ratios slightly below those on the unconstrained index (Table A.5). These findings are well in line with studies applying other sector screens on the S\&P 500 (Humphrey and Tan, 2014). For the FTSE 100, we observe below-market Sharpe ratios of the divested index (Table A.8), weak evidence that fossil fuel stocks in the index outperform (Table A.9), but insignificant underperformance of the fossil-free index. Note that differences in sample periods (1964-2016 for the S\&P 500 and 1996-2016 for the FTSE 100) may influence our findings. Finally, note that the R-squared in the regression of the returns of fossil-free portfolios on the Carhart factors diverges more heavily from 1 compared to our main analysis based on the CRSP market portfolio. This means that divestment could induce substantial tracking error when applied to a more constrained market index, such as the FTSE 100 (cf. Andersson et al., 2016).

\section{GARCH(1,1) regression}

\footnotetext{
${ }^{8}$ We use NACE 05, 0892, 0990, and 1910 for coal, and NACE 06, 0910, 1920, 2011, and 4950 for oil and gas. 9 http://business-school.exeter.ac.uk/research/centres/xfi/famafrench/files/ (accessed: September 20, 2017). Results are robust to using the Fama-French European factors.
} 
We further address time-varying volatility (volatility clustering) present in our sample directly by modeling it as a GARCH(1,1) process. Results for the GARCH $(1,1)$ model, included in Table A.12, remain qualitatively similar as our OLS estimates.

In summary, we are confident of our findings as they seem to uphold across time, in alternative and smaller investment portfolios (indices), and when using alternative regression model specifications.

\section{Conclusion}

Fossil fuel divestment campaigns insist that investors must sell their stakes in companies that supply coal, oil, or gas. We investigate whether such divestment would have had a material impact on portfolio performance. For various categories of fossil fuel companies and market indices we find that divested (fossil-free) portfolios would not have significantly underperformed the unconstrained market portfolio over a comprehensive time frame. These findings are in line with the literature on the effects of SRI and screening (Humphrey and Tan, 2014; Lobe and Walkshäusl, 2016), which usually focus on much smaller industries.

The absence of diversification costs from divestment can be explained by the fact that fossil fuel company stocks have thus far not outperformed other stocks on a risk-adjusted basis and only provide relatively limited diversification benefits. We find that fossil fuel stocks are more or less substitutes for the market index (which has a beta of 1), which contradicts the findings by Fischell (2015), and that the current focus on fossil fuel production induces only limited sector bias in divested portfolios. Our analysis suggests that it is important to systematically analyze the implications of fossil fuel divestment for portfolio performance based on standard methods in the finance literature, using a comprehensive sample and study period, and assessing the robustness of results (cf. Cornell, 2015; Fischell, 2015; Heaps et al., 2016). Notably, we find the underperformance of fossil fuel stocks in the most recent period (2011-2016) to be attributable to the negative oil price shock in that period. The divestment movement may thus benefit from shifting focus from financial arguments to its potential merits as a tool to address climate change. However, the environmental benefits (carbon emissions reductions) caused by divestment are contestable and have not been systematically analyzed yet.

A limitation of our study is that it is retrospective and static. As such, the effect of divestment on prices and expected returns remains to be seen. Continued growth of investor 
commitment to fossil fuel divestment may be expected to lower demand and prices for fossil fuel investments relative to fossil-free ones, inducing higher returns on the former and lower returns on the latter category (Dam and Scholtens, 2015; Heinkel et al., 2001). The effect on the returns of fossil fuel and fossil-free investment thus ultimately depends on investors' willingness-to-accept the controversial character of their investments in fossil fuel stocks. Moreover, a broader scope of fossil fuel divestment, which considers the intimate connections between fossil fuel supply and economic activity (see Ritchie and Dowlatabadi, 2014), might result in more pronounced implications for portfolio performance (cf. Battiston et al., 2017). Future research could apply our portfolio approach to assess the system-wide impacts of divestment on prices of a broader range of fossil fuel intensive industries. At the same time, investors might apply less restrictive approaches to reduce the carbon footprint of their investment portfolios, and thereby limit diversification costs (Andersson et al., 2016). A second limitation is that we abstract from any additional financial costs that divestment might impose, such as selection, transaction, and monitoring costs. The size of these costs should be assessed on a case by case basis, as they will be highly sensitive to the type, size, and objectives of the investment.

In all, our study calls for a careful consideration of the pro's and con's of divestment as a tool to address climate change. Our study has focused on the financial dimension of fossil fuel divestment. We feel that especially future study is needed on the environmental and social outcomes associated with divestment and other responsible investing strategies.

\section{Acknowledgements}

We are grateful to Rients Galema and Gbenga Ibikunle for their valuable comments on an earlier version of this paper. We thank Alessandro Alvarenga, Giulia Boi, Johan Trinks, and David Holwerda for proofreading and helpful suggestions. Thanks also to the editor and three anonymous reviewers of Ecological Economics for providing very useful comments and suggestions on previous versions of the manuscript. The usual disclaimer applies. 


\section{References}

Allen, M. R., Frame, D. J., Huntingford, C., Jones, C. D., Lowe, J. A., Meinshausen, M., Meinshausen, N., 2009. Warming caused by cumulative carbon emissions towards the trillionth tonne. Nature, 458(7242), 1163-1166.

Andersson, M., Bolton, P., Samama, F., 2016. Heding Climate Risk. Financial Analysts Journal, 72(3), 13-32.

Ansar, A., Caldecott, B., Tilbury, J., 2013. Stranded assets and the fossil fuel divestment campaign: what does divestment mean for the valuation of fossil fuel assets? Smith School of Enterprise and the Environment, University of Oxford.

Arbuthnott, K. D., Dolter, B., 2013. Escalation of commitment to fossil fuels. Ecological Economics, 89, 7-13.

Auer, B. R., 2016. Do Socially Responsible Investment Policies Add or Destroy European Stock Portfolio Value? Journal of Business Ethics, 135(2), 381-397.

Ayling, J., Gunningham, N., 2017. Non-state governance and climate policy: the fossil fuel divestment movement. Climate Policy, 17(2), 131-149.

Battiston, S., Mandel, A., Monasterolo, I., Schütze, F., Visentin, G., 2017. A climate stresstest of the financial system. Nature Climate Change, 7(4), 283-288.

Bello, Z. Y., 2005. Socially responsible investing and portfolio diversification. The Journal of Financial Research, 28(1), 41-57.

Bessembinder, H., 2016. Frictional Costs of Fossil Fuel Divestment. Unpublished results. https://ssrn.com/abstract=2789878 (accessed: July 11, 2017).

Bollerslev, T., Wooldridge, J. M., 1992. Quasi-maximum likelihood estimation and inference in dynamic models with time-varying covariances. Econometric Reviews, 11(2), 143-172. 
Busch, T., Hoffmann, V. H., 2007. Emerging carbon constraints for corporate risk management. Ecological Economics, 62(3), 518-528.

Busch, T., Lewandowski, S., 2017. Corporate Carbon and Financial Performance: A Metaanalysis. Journal of Industrial Ecology (in press). http://doi.org/10.1111/jiec.12591.

Campiglio, E., 2016. Beyond carbon pricing: The role of banking and monetary policy in financing the transition to a low-carbon economy. Ecological Economics, 121, 220-230.

Carhart, M. M., 1997. On persistence in mutual fund performance. The Journal of Finance, 52(1), 57-82.

Cochrane, J. H., 2008. The Dog That Did Not Bark: A Defense of Return Predictability. The Review of Financial Studies, 21(4), 1533-1575.

Cornell, B., 2015. The Divestment Penalty: Estimating the Costs of Fossil Fuel Divestment to Select University Endowments. http://dx.doi.org/10.2139/ssrn.2655603 (accessed: July 11, 2017).

Dam, L., Scholtens, B., 2015. Toward a theory of responsible investing: On the economic foundations of corporate social responsibility. Resource and Energy Economics, 41, 103-121.

De Jong, M., Nguyen, A., 2016. Weathered for Climate Risk: A Bond Investment Proposition. Financial Analysts Journal, 72(3), 34-39.

Dietz, S., Bowen, A., Dixon, C., Gradwell, P., 2016. 'Climate value at risk’ of global financial assets. Nature Climate Change, 6(7), 676-679.

Driesprong, G., Jacobsen, B., Maat, B., 2008. Striking oil: Another puzzle? Journal of Financial Economics, 89(2), 307-327.

Eurosif, 2016. European SRI Study. http://www.eurosif.org/sri-study-2016/ (accessed: July 3, 2017). 
Evans, J. L., Archer, S. H., 1968. Diversification and the reduction of dispersion: an empirical analysis. The Journal of Finance, 23(5), 761-767.

Fama, E. F., French, K. R., 1997. Industry costs of equity. Journal of Financial Economics, 43(2), 153-193.

Fama, E. F., French, K. R., 2007. Disagreement, tastes, and asset prices. Journal of Financial Economics, 83(3), 667-689.

Fischel, D. R., 2015. Fossil Fuel Divestment: A Costly and Ineffective Investment Strategy. http://divestmentfacts.com/pdf/Fischel_Report.pdf (accessed: July 11, 2017).

Fu, F., 2009. Idiosyncratic risk and the cross-section of expected stock returns. Journal of Financial Economics, 91(1), 24-37.

Galema, R., Scholtens, B., Plantinga, A., 2008. The stocks at stake: Return and risk in socially responsible investment. Journal of Banking \& Finance, 32(12), 2646-2654.

Global Sustainable Investment Alliance, 2016. Global Sustainable Investment Review. http://www.gsi-alliance.org/members-resources/trends-report-2016/ (accessed: July 3, 2017).

Goyal, A., Santa-Clara, P., 2003. Idiosyncratic risk matters! The Journal of Finance, 58(3), 975-1007.

Gregory, A., Tharyan, R., Christidis, A., 2013. Constructing and testing alternative versions of the Fama-French and Carhart models in the UK. Journal of Business Finance \& Accounting, 40(1-2), 172-214.

Griffin, P. A., Jaffe, A. M., Lont, D. H., Dominguez-Faus, R., 2015. Science and the stock market: Investors' recognition of unburnable carbon. Energy Economics, 52(PA), 1-12.

Gross, M., 2015. Twenty-five years of climate change failure. Current Biology, 25(8), R307R310. 
Heaps, T., Yow, M., Behar, A., 2016. Carbon Clean 200: Investing In A Clean Energy Future. Corporate Knights and As You Sow. http://www.clean200.org/ (accessed: September 29, 2017).

Heede, R., 2014. Tracing anthropogenic carbon dioxide and methane emissions to fossil fuel and cement producers, 1854-2010. Climatic Change, 122(1), 229-241.

Heinkel, R., Kraus, A., Zechner, J., 2001. The Effect of Green Investment on Corporate Behavior. Journal of Financial and Quantitative Analysis, 36(4), 431-449.

Hoepner, A. G., Schopohl, L., 2016. On the Price of Morals in Markets: An Empirical Study of the Swedish AP-Funds and the Norwegian Government Pension Fund. Journal of Business Ethics, 1-28. http://dx.doi.org/10.1007/s10551-016-3261-0.

Hong, H., Kacperczyk, M., 2009. The price of sin: The effects of social norms on markets. Journal of Financial Economics, 93(1), 15-36.

Humphrey, J. E., Tan, D. T., 2014. Does it really hurt to be responsible? Journal of Business Ethics, 122(3), 375-386.

Ibikunle, G., Steffen, T., 2015. European green mutual fund performance: a comparative analysis with their conventional and black peers. Journal of Business Ethics, 1-19. http://dx.doi.org/10.1007/s10551-015-2850-7.

Jobson, J. D., Korkie, B. M., 1981. Performance hypothesis testing with the Sharpe and Treynor measures. The Journal of Finance, 36(4), 889-908.

Leaton, J., 2011. Unburnable Carbon - Are the world's financial markets carrying a carbon bubble? Carbon Tracker Initiative, London, UK. http://www.carbontracker.org/report/carbonbubble/ (accessed: July 17, 2017).

Ledoit, O., Wolf, M., 2008. Robust performance hypothesis testing with the Sharpe ratio. Journal of Empirical Finance, 15(5), 850-859. 
Ledoit, O., Wolf, M., 2011. Robust performances hypothesis testing with the variance. Wilmott, 2011(55), 86-89.

Liesen, A., Figge, F., Hoepner, A., Patten, D. M., 2017. Climate Change and Asset Prices: Are Corporate Carbon Disclosure and Performance Priced Appropriately? Journal of Business Finance \& Accounting, 44(1) \& (2), 35-62.

Lobe, S., Walkshäusl, C., 2016. Vice versus virtue investing around the world. Review of Managerial Science, 10(2), 303-344.

Luo, H. A., Balvers, R. J., 2017. Social Screens and Systematic Investor Boycott Risk. Journal of Financial and Quantitative Analysis, 52(1), 365-399.

Markowitz, H., 1952. Portfolio selection. The Journal of Finance, 7(1), 77-91.

McGlade, C., Ekins, P., 2015. The geographical distribution of fossil fuels unused when limiting global warming to $2^{\circ} \mathrm{C}$. Nature, 517(7533), 187-190.

Meinshausen, M., Meinshausen, N., Hare, W., Raper, S. C., Frieler, K., Knutti, R., Frame, D., Allen, M. R., 2009. Greenhouse-gas emission targets for limiting global warming to $2{ }^{\circ} \mathrm{C}$. Nature, 458(7242), 1158-1162.

Memmel, C., 2003. Performance Hypothesis Testing with the Sharpe Ratio. Finance Letters, 1(1), 21-23.

Newey, W. K., West, K. D., 1987. A Simple, Positive Semi-Definite, Heteroskedasticity and Autocorrelation Consistent Covariance Matrix. Econometrica, 55(3), 703-708.

Nofsinger, J., Varma, A., 2014. Socially responsible funds and market crises. Journal of Banking \& Finance, 48, 180-193. 
Revelli, C., Viviani, J., 2015. Financial performance of socially responsible investing (SRI): what have we learned? A meta-analysis. Business Ethics: A European Review, 24(2), 158185.

Ritchie, J., Dowlatabadi, H., 2014. Understanding the shadow impacts of investment and divestment decisions: Adapting economic input-output models to calculate biophysical factors of financial returns. Ecological Economics, 106, 132-140.

Ritchie, J., Dowlatabadi, H., 2015. Divest from the Carbon Bubble? Reviewing the Implications and Limitations of Fossil Fuel Divestment for Institutional Investors. Review of Economics \& Finance, 5, 59-80.

Roy, A.D. 1952. Safety First and the Holding of Assets. Econometrica, 20(3), 431-449.

Rudd, A., 1981. Social Responsibility and Portfolio Performance. California Management Review, 23(4), 55-61.

Scholtens, B., 2014. Indicators of responsible investing. Ecological Indicators, 36, 382-385.

Scholtens, B., 2017. Why Finance Should Care about Ecology. Trends in Ecology \& Evolution, 32(7), 500-505.

Scholtens, B., Yurtsever, C., 2012. Oil price shocks and European industries. Energy Economics, 34(4), 1187-1195.

Schwarz, R., 2015. Reinvesting after Divesting: A Few Fossil-Fuel-Free Options. The Journal of Environmental Investing, 6(1), 42-46.

Sharpe, W.F., 1964. Capital Asset Prices: A Theory of Market Equilibrium under Conditions of Risk. The Journal of Finance, 19(3), 425-442.

Sharpe, W. F., 1966. Mutual Fund Performance, The Journal of Business, 39(1), 119-138. 
Sortino, F. A., Van der Meer, R., 1991. Downside risk. The Journal of Portfolio Management, 17(4), 27-31.

Statman, M., 1987. How many stocks make a diversified portfolio? Journal of Financial and Quantitative Analysis, 22(3), 353-363.

Tobin, J., 1958. Liquidity Preference as Behavior towards Risk. Review of Economic Studies, 25(1), 65-86.

Trinks, P. J., Scholtens, B., 2017. The Opportunity Cost of Negative Screening in Socially Responsible Investing. Journal of Business Ethics, 140(2), 193-208.

Van den Bergh, J. C. J. M., Botzen, W. J. W., 2015. Monetary valuation of the social cost of $\mathrm{CO}_{2}$ emissions: A critical survey. Ecological Economics, 114, 33-46. 


\section{Appendix. Sensitivity analyses}

Table A.1: Risk-adjusted return performance of fossil fuel portfolios, before and after the first divestment campaigns (Carhart model, 1927-2016)

\begin{tabular}{|c|c|c|c|c|c|c|}
\hline \multicolumn{4}{|c|}{ SIC } & \multicolumn{3}{|l|}{ CU200 } \\
\hline Portfolio: & Coal & Oil and gas & All fossil fuels & Coal & Oil and gas & All fossil fuels \\
\hline MktRf & $\begin{array}{l}0.0709 \\
(0.0602)\end{array}$ & $\begin{array}{l}-0.1046 * * \\
(0.0475)\end{array}$ & $\begin{array}{l}-0.1004 * * \\
(0.0473)\end{array}$ & $\begin{array}{l}-0.0452 \\
(0.0975)\end{array}$ & $\begin{array}{l}-0.0269 \\
(0.0742)\end{array}$ & $\begin{array}{l}0.0043 \\
(0.0673)\end{array}$ \\
\hline SMB & $\begin{array}{l}0.4405^{* * *} \\
(0.1200)\end{array}$ & $\begin{array}{l}-0.2387^{* * *} \\
(0.0544)\end{array}$ & $\begin{array}{l}-0.2304 * * * \\
(0.0545)\end{array}$ & $\begin{array}{l}-0.0582 \\
(0.1149)\end{array}$ & $\begin{array}{l}-0.2826^{* * *} \\
(0.1024)\end{array}$ & $\begin{array}{l}-0.2579 * * * \\
(0.0933)\end{array}$ \\
\hline HML & $\begin{array}{l}0.6536 * * * \\
(0.1234)\end{array}$ & $\begin{array}{l}0.2750 * * * \\
(0.0703)\end{array}$ & $\begin{array}{l}0.2829 * * * \\
(0.0693)\end{array}$ & $\begin{array}{l}0.5147 * * * \\
(0.1899)\end{array}$ & $\begin{array}{l}0.5408 * * * \\
(0.1401)\end{array}$ & $\begin{array}{l}0.6388 * * * \\
(0.1365)\end{array}$ \\
\hline WML & $\begin{array}{l}-0.1628 \\
(0.1085)\end{array}$ & $\begin{array}{l}0.1025^{*} \\
(0.0614)\end{array}$ & $\begin{array}{l}0.0995 \\
(0.0604)\end{array}$ & $\begin{array}{l}-0.0332 \\
(0.1017)\end{array}$ & $\begin{array}{l}0.0159 \\
(0.0876)\end{array}$ & $\begin{array}{l}0.0057 \\
(0.0811)\end{array}$ \\
\hline Divestment & $\begin{array}{l}-0.0294^{* *} \\
(0.0145)\end{array}$ & $\begin{array}{l}-0.0060 \\
(0.0047)\end{array}$ & $\begin{array}{l}-0.0065 \\
(0.0047)\end{array}$ & $\begin{array}{l}-0.0151^{* * *} \\
(0.0053)\end{array}$ & $\begin{array}{l}-0.0107 * \\
(0.0063)\end{array}$ & $\begin{array}{l}-0.0107 * * \\
(0.0052)\end{array}$ \\
\hline Alpha & $\begin{array}{l}-0.0014 \\
(0.0021)\end{array}$ & $\begin{array}{l}0.0007 \\
(0.0012)\end{array}$ & $\begin{array}{l}0.0006 \\
(0.0012)\end{array}$ & $\begin{array}{l}0.0009 \\
(0.0031)\end{array}$ & $\begin{array}{l}0.0035 * \\
(0.0019)\end{array}$ & $\begin{array}{l}0.0015 \\
(0.0021)\end{array}$ \\
\hline $\begin{array}{l}\mathrm{N} \\
\mathrm{R}^{2}\end{array}$ & $\begin{array}{l}1,080 \\
0.2086\end{array}$ & $\begin{array}{l}1,080 \\
0.1016\end{array}$ & $\begin{array}{l}1,080 \\
0.0998\end{array}$ & $\begin{array}{l}750 \\
0.0445\end{array}$ & $\begin{array}{l}737 \\
0.1052\end{array}$ & $\begin{array}{l}815 \\
0.1117\end{array}$ \\
\hline
\end{tabular}

This table reports the results from regressing the monthly excess returns on a zero-investment portfolio with a long position in the fossil fuel portfolios and a corresponding short position in the CRSP market portfolio excluding fossil fuels on the Carhart (1997) US factors using OLS. The SIC industry definition includes SIC 12, 3532 (coal) and SIC 13, 291, 3533, 46, and 492 (oil and gas). CU200 is the July 2016 Carbon Underground 200 list from Fossil Free Indexes LLC of the 100 largest coal companies and 100 largest oil and gas companies based on reported reserves (http://gofossilfree.org/top-200/). Alpha is the intercept, indicating relative out- or underperformance. Divestment is a time dummy, taking on the value 1 in the period from the start of the first divestment campaigns (2011-2016) and 0 for the period before (1927-2010). MktRf, SMB, HML, and WML are the coefficients on the Market, Size, Book-to-Market, and Momentum factors respectively. Newey-West (1987) heteroskedasticity and autocorrelation consistent (HAC) standard errors are in parentheses. *** $\mathrm{p}<0.01, * * \mathrm{p}<0.05$, * $\mathrm{p}<0.10$.

Table A.2: Risk-adjusted return performance of fossil-free portfolios, before and after the first divestment campaigns (Carhart model, 1927-2016)

\begin{tabular}{|c|c|c|c|c|c|c|}
\hline & $S I C$ & & & CU200 & & \\
\hline Portfolio: & Coal & Oil and gas & All fossil fuels & Coal & Oil and gas & All fossil fuels \\
\hline MktRf & $\begin{array}{l}0.9996 * * * \\
(0.0002)\end{array}$ & $\begin{array}{l}1.0046^{* * * *} \\
(0.0079)\end{array}$ & $\begin{array}{l}1.0042 * * * \\
(0.0079)\end{array}$ & $\begin{array}{l}0.9999 * * * \\
(0.0001)\end{array}$ & $\begin{array}{l}1.0016^{* * * *} \\
(0.0008)\end{array}$ & $\begin{array}{l}1.0015 * * * \\
(0.0009)\end{array}$ \\
\hline SMB & $\begin{array}{l}-0.0007 * * * \\
(0.0002)\end{array}$ & $\begin{array}{l}0.0322 * * * \\
(0.0072)\end{array}$ & $\begin{array}{l}0.0314 * * * \\
(0.0073)\end{array}$ & $\begin{array}{l}0.0001 \\
(0.0001)\end{array}$ & $\begin{array}{l}0.0038 * * * \\
(0.0011)\end{array}$ & $\begin{array}{l}0.0039 * * * \\
(0.0011)\end{array}$ \\
\hline HML & $\begin{array}{l}-0.0012^{* * *} \\
(0.0004)\end{array}$ & $\begin{array}{l}-0.0225 * * \\
(0.0090)\end{array}$ & $\begin{array}{l}-0.0239 * * * \\
(0.0090)\end{array}$ & $\begin{array}{l}-0.0001 \\
(0.0001)\end{array}$ & $\begin{array}{l}-0.0051^{* * *} \\
(0.0012)\end{array}$ & $\begin{array}{l}-0.0052^{* * *} \\
(0.0013)\end{array}$ \\
\hline WML & $\begin{array}{l}0.0003 \\
(0.0003)\end{array}$ & $\begin{array}{l}-0.0215 * * \\
(0.0098)\end{array}$ & $\begin{array}{l}-0.0212^{* *} \\
(0.0097)\end{array}$ & $\begin{array}{l}-0.0001 \\
(0.0001)\end{array}$ & $\begin{array}{l}-0.0007 \\
(0.0011)\end{array}$ & $\begin{array}{l}-0.0008 \\
(0.0011)\end{array}$ \\
\hline Divestment & $\begin{array}{l}0.0001^{* *} \\
(0.0000)\end{array}$ & $\begin{array}{l}0.0006 \\
(0.0005)\end{array}$ & $\begin{array}{l}0.0007 \\
(0.0005)\end{array}$ & $\begin{array}{l}0.0001 * * * \\
(0.0000)\end{array}$ & $\begin{array}{l}0.0002 \\
(0.0001)\end{array}$ & $\begin{array}{l}0.0002 * \\
(0.0001)\end{array}$ \\
\hline Alpha & $\begin{array}{l}0.0000^{*} \\
(0.0000)\end{array}$ & $\begin{array}{l}0.0001 \\
(0.0002)\end{array}$ & $\begin{array}{l}0.0001 \\
(0.0002)\end{array}$ & $\begin{array}{l}-0.0000 \\
(0.0000)\end{array}$ & $\begin{array}{l}-0.0000 \\
(0.0000)\end{array}$ & $\begin{array}{l}-0.0000 \\
(0.0000)\end{array}$ \\
\hline $\mathrm{N}$ & 1,080 & 1,080 & 1,080 & 1,080 & 1,080 & 1,080 \\
\hline $\mathrm{R}^{2}$ & 1.0000 & 0.9888 & 0.9885 & 1.0000 & 0.9997 & 0.9997 \\
\hline
\end{tabular}

This table reports the results from regressing the monthly excess returns on the zero-investment portfolio with a long position in the fossilfree portfolio and a short position in the unconstrained market portfolio on the Carhart (1997) US factors using OLS. The SIC industry definition includes SIC 12, 3532 (coal) and SIC 13, 291, 3533, 46, and 492 (oil and gas). CU200 is the July 2016 Carbon Underground 200 list from Fossil Free Indexes LLC of the 100 largest coal companies and 100 largest oil and gas companies based on reported reserves (http://gofossilfree.org/top-200/). Alpha is the intercept, indicating relative out- or underperformance. Divestment is a time dummy, taking on the value 1 in the period from the start of the first divestment campaigns (2011-2016) and 0 for the period before (1927-2010). MktRf, SMB, HML, and WML are the coefficients on the Market, Size, Book-to-Market, and Momentum factors respectively. Newey-West (1987) heteroskedasticity and autocorrelation consistent (HAC) standard errors are in parentheses. ${ }^{* * *} \mathrm{p}<0.01,{ }^{* *} \mathrm{p}<0.05,{ }^{*} \mathrm{p}<0.10$. 
Table A.3: Difference between Sharpe ratio of fossil-free portfolio and market portfolio (15-year subsamples) $\Delta$ Sharpe Alpha fossil-free Alpha fossil fuel Beta fossil fuel \%stocks fossil fuel \%market cap. fossil fuel

\begin{tabular}{|c|c|c|c|c|c|c|}
\hline $1927-1941$ & 0.0032 & 0.0003 & -0.0013 & 0.85 & 8.5 & 13.9 \\
\hline $1942-1956$ & -0.0133 & -0.0001 & 0.0007 & 1.02 & 7.1 & 17.7 \\
\hline 1957-1971 & 0.0049 & 0.0002 & -0.0005 & 0.96 & 7.4 & 16.0 \\
\hline $1972-1986$ & -0.0080 & 0.0001 & 0.0012 & 1.04 & 7.8 & 16.4 \\
\hline $1987-2001$ & -0.0016 & 0.0002 & -0.0008 & 0.82 & 6.0 & 8.6 \\
\hline $2002-2016$ & -0.0022 & 0.0001 & 0.0007 & 1.04 & 5.7 & 10.3 \\
\hline Average & -0.0028 & 0.0001 & 0.0000 & 0.96 & 7.1 & 13.8 \\
\hline
\end{tabular}

This table shows the performance of portfolios with and without fossil fuel stocks (SIC industry definition) over 15-year time frames. The SIC industry definition includes SIC 12, 3532 (coal) and SIC 13, 291, 3533, 46, and 492 (oil and gas). $\Delta$ Sharpe is the difference between the Sharpe ratio of the fossil-free portfolio and the unconstrained CRSP market portfolio. ${ }^{* * *} \mathrm{p}<0.01,{ }^{* *} \mathrm{p}<0.05,{ }^{*} \mathrm{p}<0.10$, with ${ }^{\mathrm{F}}$ denoting the F-test for equality of variances and $\mathrm{LW}$ the robust Ledoit-Wolf (2011) alternative using the studentized time series bootstrapping procedure with 5,000 resamples. Alpha fossil-free is the alpha coefficient in a regression of fossil-free portfolio excess returns on the Carhart (1997) US factors using OLS. Alpha fossil is the alpha coefficient (constant) in a regression of the excess returns on the zero-investment portfolio with a long position in the fossil fuel portfolios and a corresponding short position in the CRSP market portfolio excluding fossil fuels on the Carhart (1997) US factors using OLS. Beta fossil is the loading on the market factor in a regression of fossil fuel portfolio excess returns on the Carhart (1997) US factors using OLS. \%stocks fossil and \%market cap. fossil are the percentage shares of fossil fuel stocks in the market portfolio in terms of number of stocks and market capitalization respectively.

Table A.4: Descriptive statistics and performance ratios of fossil-free S\&P 500 portfolios (1964-2016)

\begin{tabular}{|c|c|c|c|c|c|c|c|c|c|}
\hline & & Mean & Median & StDev & DR & Sharpe & Sortino & $\Delta \operatorname{Var}$ & $\Delta$ Sharpe \\
\hline S\&P 500 & Market portfolio & $0.50 \%$ & $0.72 \%$ & $4.22 \%$ & $4.24 \%$ & 0.1176 & 0.1169 & - & - \\
\hline \multicolumn{10}{|c|}{ Fossil-free portfolios } \\
\hline \multirow{3}{*}{$\begin{array}{l}\text { SIC broad } \\
\text { def. }\end{array}$} & Market excl. Coal & $0.50 \%$ & $0.72 \%$ & $4.21 \%$ & $4.24 \%$ & 0.1178 & 0.1170 & $-0.0002 \%$ & 0.0002 \\
\hline & Market excl. Oil and gas & $0.49 \%$ & $0.69 \%$ & $4.33 \%$ & $4.35 \%$ & 0.1128 & 0.1122 & $0.0094 \%$ & -0.0048 \\
\hline & Market excl. All fossil fuels & $0.49 \%$ & $0.68 \%$ & $4.32 \%$ & $4.35 \%$ & 0.1130 & 0.1124 & $0.0093 \%$ & -0.0046 \\
\hline \multirow[t]{3}{*}{ CU200 } & Market excl. Coal & $0.50 \%$ & $0.73 \%$ & $4.22 \%$ & $4.24 \%$ & 0.1177 & 0.1170 & $0.0001 \%$ & 0.0001 \\
\hline & Market excl. Oil and gas & $0.49 \%$ & $0.70 \%$ & $4.24 \%$ & $4.27 \%$ & 0.1160 & 0.1153 & $0.0024 \%$ & -0.0016 \\
\hline & Market excl. All fossil fuels & $0.49 \%$ & $0.70 \%$ & $4.24 \%$ & $4.27 \%$ & 0.1161 & 0.1154 & $0.0025 \%$ & -0.0015 \\
\hline
\end{tabular}

This table presents the mean, standard deviation, and downside risk (DR) of monthly excess returns on the fossil fuel and fossil-free portfolios, as well as their Sharpe and Sortino ratios over the period 01/1964-12/2016 (N=635). The SIC industry definition includes SIC 12, 3532 (coal) and SIC 13, 291, 3533, 46, and 492 (oil and gas). CU200 is the July 2016 Carbon Underground 200 list from Fossil Free Indexes LLC of the 100 largest coal companies and 100 largest oil and gas companies based on reported reserves (http://gofossilfree.org/top-200/). $\Delta \operatorname{Var}$ is the difference between each portfolio's variance and the variance of the S\&P 500 market portfolio. ${ }^{* * *} \mathrm{p}<0.01,{ }^{* *} \mathrm{p}<0.05,{ }^{*} \mathrm{p}<0.10$, with ${ }^{\mathrm{F}}$ denoting the F-test for equality of variances and ${ }^{\mathrm{LW}}$ the robust Ledoit-Wolf (2011) alternative using the studentized time series bootstrapping procedure with 5,000 resamples. $\Delta$ Sharpe is the difference between each portfolio's Sharpe ratio and that of the S\&P 500 market portfolio. ${ }^{\mathrm{JK}}$ denotes the Jobson-Korkie (1981) test of equal Sharpe ratios and ${ }^{\mathrm{LW}}$ the robust Ledoit-Wolf (2008) alternative using the studentized time series bootstrapping procedure with 5,000 resamples. 
Table A.5: Risk-adjusted return performance of S\&P 500 fossil fuel portfolios (Carhart model, 1964-2016)

\begin{tabular}{|c|c|c|c|c|c|c|}
\hline \multicolumn{4}{|c|}{ SIC } & \multicolumn{3}{|l|}{ CU200 } \\
\hline Portfolio: & Coal & Oil and gas & All fossil fuels & Coal & Oil and gas & All fossil fuels \\
\hline MktRf & $\begin{array}{l}0.2546 * * * \\
(0.0936)\end{array}$ & $\begin{array}{l}-0.0879 \\
(0.0661)\end{array}$ & $\begin{array}{l}-0.0838 \\
(0.0660)\end{array}$ & $\begin{array}{l}-0.2405^{* *} \\
(0.1063)\end{array}$ & $\begin{array}{l}0.3442 \\
(0.4162)\end{array}$ & $\begin{array}{l}0.2665 \\
(0.3941)\end{array}$ \\
\hline SMB & $\begin{array}{l}0.4678^{* * *} \\
(0.1651)\end{array}$ & $\begin{array}{l}-0.1633^{* *} \\
(0.0822)\end{array}$ & $\begin{array}{l}-0.1587 * \\
(0.0825)\end{array}$ & $\begin{array}{l}-0.0392 \\
(0.1677)\end{array}$ & $\begin{array}{l}-0.2211 \\
(0.1965)\end{array}$ & $\begin{array}{l}-0.2697 \\
(0.1832)\end{array}$ \\
\hline HML & $\begin{array}{l}0.1362 \\
(0.1903)\end{array}$ & $\begin{array}{l}0.3548 * * * \\
(0.1152)\end{array}$ & $\begin{array}{l}0.3565^{* * * *} \\
(0.1158)\end{array}$ & $\begin{array}{l}0.2393 \\
(0.2249)\end{array}$ & $\begin{array}{l}1.3405 \\
(0.8448)\end{array}$ & $\begin{array}{l}1.2319 \\
(0.8015)\end{array}$ \\
\hline WML & $\begin{array}{l}0.0760 \\
(0.1594)\end{array}$ & $\begin{array}{l}0.1072 \\
(0.0839)\end{array}$ & $\begin{array}{l}0.1077 \\
(0.0843)\end{array}$ & $\begin{array}{l}-0.0127 \\
(0.1132)\end{array}$ & $\begin{array}{l}-0.2138 \\
(0.2957)\end{array}$ & $\begin{array}{l}-0.2274 \\
(0.2889)\end{array}$ \\
\hline Alpha & $\begin{array}{l}-0.0047 \\
(0.0041)\end{array}$ & $\begin{array}{l}0.0002 \\
(0.0016)\end{array}$ & $\begin{array}{l}0.0001 \\
(0.0016)\end{array}$ & $\begin{array}{l}-0.0023 \\
(0.0033)\end{array}$ & $\begin{array}{l}0.0125 \\
(0.0112)\end{array}$ & $\begin{array}{l}0.0117 \\
(0.0106)\end{array}$ \\
\hline $\mathrm{N}$ & 524 & 635 & 635 & 538 & 539 & 586 \\
\hline $\mathrm{R}^{2}$ & 0.0457 & 0.0938 & 0.0919 & 0.0276 & 0.0157 & 0.0147 \\
\hline
\end{tabular}

This table reports the results from regressing the monthly excess returns on the zero-investment portfolio with a long position in the fossil fuel portfolios and a corresponding short position in the S\&P 500 market portfolio excluding fossil fuels on the Carhart (1997) US factors using OLS. ). The SIC industry definition includes SIC 12, 3532 (coal) and SIC 13, 291, 3533, 46, and 492 (oil and gas). CU200 is the July 2016 Carbon Underground 200 list from Fossil Free Indexes LLC of the 100 largest coal companies and 100 largest oil and gas companies based on reported reserves (http://gofossilfree.org/top-200/). Alpha is the intercept, indicating relative out- or underperformance. MktRf, SMB, HML, and WML are the coefficients on the Market, Size, Book-to-Market, and Momentum factors respectively. Newey-West (1987) heteroskedasticity and autocorrelation consistent (HAC) standard errors are in parentheses. ${ }^{* * *} \mathrm{p}<0.01$, ${ }^{* *} \mathrm{p}<0.05,{ }^{*} \mathrm{p}<0.10$.

Table A.6: Risk-adjusted return performance of fossil-free S\&P 500 portfolios (Carhart model, 1964-2016)

\begin{tabular}{|c|c|c|c|c|c|c|}
\hline & \multicolumn{3}{|l|}{ SIC } & \multicolumn{3}{|l|}{ CU200 } \\
\hline Portfolio: & Coal & Oil and gas & All fossil fuels & Coal & Oil and gas & All fossil fuels \\
\hline MktRf & $\begin{array}{l}0.9995 * * * \\
(0.0002)\end{array}$ & $\begin{array}{l}1.0021^{* * *} \\
(0.0111)\end{array}$ & $\begin{array}{l}1.0015 * * * \\
(0.0112)\end{array}$ & $\begin{array}{l}1.0002 * * * \\
(0.0001)\end{array}$ & $\begin{array}{l}1.0033^{* * *} \\
(0.0021)\end{array}$ & $\begin{array}{l}1.0036 * * * \\
(0.0021)\end{array}$ \\
\hline SMB & $\begin{array}{l}-0.0003 \\
(0.0002)\end{array}$ & $\begin{array}{l}0.0273 * * \\
(0.0119)\end{array}$ & $\begin{array}{l}0.0270 * * \\
(0.0120)\end{array}$ & $\begin{array}{l}0.0001 \\
(0.0001)\end{array}$ & $\begin{array}{l}0.0032 \\
(0.0024)\end{array}$ & $\begin{array}{l}0.0034 \\
(0.0024)\end{array}$ \\
\hline HML & $\begin{array}{l}-0.0002 \\
(0.0004)\end{array}$ & $\begin{array}{l}-0.0251 \\
(0.0168)\end{array}$ & $\begin{array}{l}-0.0253 \\
(0.0170)\end{array}$ & $\begin{array}{l}-0.0000 \\
(0.0003)\end{array}$ & $\begin{array}{l}-0.0112 * * * \\
(0.0036)\end{array}$ & $\begin{array}{l}-0.0112^{* * *} \\
(0.0036)\end{array}$ \\
\hline WML & $\begin{array}{l}-0.0002 \\
(0.0002)\end{array}$ & $\begin{array}{l}-0.0257^{*} \\
(0.0155)\end{array}$ & $\begin{array}{l}-0.0260 * \\
(0.0157)\end{array}$ & $\begin{array}{l}-0.0002 \\
(0.0001)\end{array}$ & $\begin{array}{l}-0.0007 \\
(0.0023)\end{array}$ & $\begin{array}{l}-0.0009 \\
(0.0023)\end{array}$ \\
\hline Alpha & $\begin{array}{l}0.0000 \\
(0.0000)\end{array}$ & $\begin{array}{l}0.0001 \\
(0.0002)\end{array}$ & $\begin{array}{l}0.0001 \\
(0.0002)\end{array}$ & $\begin{array}{l}0.0000 * \\
(0.0000)\end{array}$ & $\begin{array}{l}-0.0000 \\
(0.0001)\end{array}$ & $\begin{array}{l}-0.0000 \\
(0.0001)\end{array}$ \\
\hline $\begin{array}{l}\mathrm{N} \\
\mathrm{R}^{2}\end{array}$ & $\begin{array}{l}635 \\
1.0000\end{array}$ & $\begin{array}{l}635 \\
0.9776\end{array}$ & $\begin{array}{l}635 \\
0.9772\end{array}$ & $\begin{array}{l}635 \\
1.0000\end{array}$ & $\begin{array}{l}635 \\
0.9989\end{array}$ & $\begin{array}{l}635 \\
0.9989\end{array}$ \\
\hline
\end{tabular}

This table reports the results from regressing the monthly excess returns on the zero-investment portfolio with a long position in the fossilfree portfolio and a short position in the unconstrained market portfolio on the Carhart (1997) US factors using OLS. The SIC industry definition includes SIC 12, 3532 (coal) and SIC 13, 291, 3533, 46, and 492 (oil and gas). CU200 is the July 2016 Carbon Underground 200 list from Fossil Free Indexes LLC of the 100 largest coal companies and 100 largest oil and gas companies based on reported reserves (http://gofossilfree.org/top-200/). Alpha is the intercept, indicating relative out- or underperformance. MktRf, SMB, HML, and WML are the coefficients on the Market, Size, Book-to-Market, and Momentum factors respectively. Newey-West (1987) heteroskedasticity and autocorrelation consistent (HAC) standard errors are in parentheses. ${ }^{* * *} \mathrm{p}<0.01,{ }^{* *} \mathrm{p}<0.05$, ${ }^{*} \mathrm{p}<0.10$. 
Figure A.1: Year-average percentage share of fossil fuel companies in the FTSE 100 index

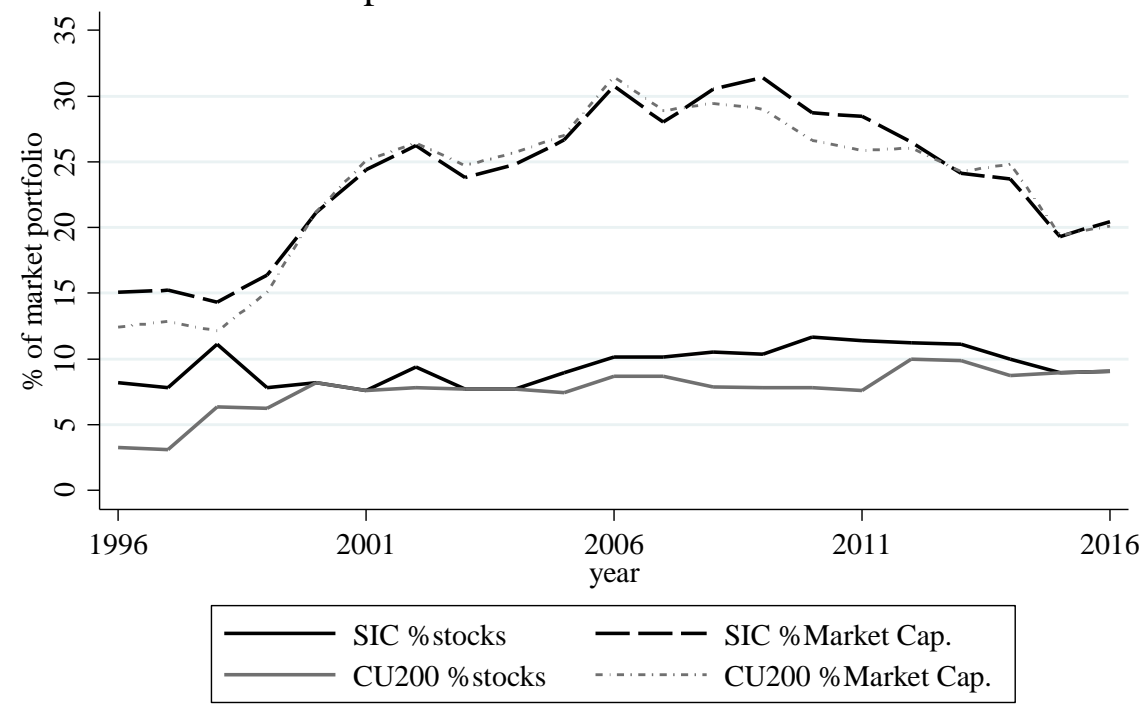

\section{Verander streepjes pattroon, en neem iets lichtere grijstint}

Table A.7: Descriptive statistics and performance ratios of fossil-free FTSE 100 portfolios (1996-2016)

\begin{tabular}{|c|c|c|c|c|c|c|c|c|c|}
\hline & & Mean & Median & StDev & DR & Sharpe & Sortino & $\Delta$ Var & $\Delta$ Sharpe \\
\hline FTSE 100 & Market portfolio & $0.59 \%$ & $0.96 \%$ & $3.73 \%$ & $3.77 \%$ & 0.1589 & 0.1572 & - & - \\
\hline \multicolumn{10}{|c|}{ Fossil-free portfolios } \\
\hline \multirow[t]{3}{*}{ SIC } & Market excl. Coal & $0.58 \%$ & $0.89 \%$ & $3.69 \%$ & $3.73 \%$ & 0.1582 & 0.1556 & $-0.0034 \%$ & -0.0007 \\
\hline & Market excl. Oil and gas & $0.60 \%$ & $0.84 \%$ & $3.77 \%$ & $3.81 \%$ & 0.1598 & 0.1581 & $0.0026 \%$ & 0.0009 \\
\hline & Market excl. All fossil fuels & $0.59 \%$ & $0.86 \%$ & $3.72 \%$ & $3.76 \%$ & 0.1588 & 0.1571 & $-0.0011 \%$ & -0.0001 \\
\hline \multirow[t]{3}{*}{ CU200 } & Market excl. Coal & $0.59 \%$ & $1.03 \%$ & $3.64 \%$ & $3.68 \%$ & 0.1620 & 0.1602 & $-0.0073 \%$ & 0.0031 \\
\hline & Market excl. Oil and gas & $0.59 \%$ & $0.94 \%$ & $3.69 \%$ & $3.73 \%$ & 0.1598 & 0.1581 & $-0.0029 \%$ & 0.0009 \\
\hline & Market excl. All fossil fuels & $0.60 \%$ & $0.95 \%$ & $3.64 \%$ & $3.68 \%$ & 0.1642 & 0.1624 & $-0.0069 \%$ & 0.0053 \\
\hline
\end{tabular}

This table presents the mean, standard deviation, and downside risk (DR) of monthly excess returns of the fossil fuel and fossil-free portfolios, as well as their Sharpe and Sortino ratios over the period 01/1996-12/2016 (N=251). The SIC industry definition includes SIC 12, 3532 (coal) and SIC 13, 291, 3533, 46, and 492 (oil and gas). CU200 is the July 2016 Carbon Underground 200 list from Fossil Free Indexes LLC of the 100 largest coal companies and 100 largest oil and gas companies based on reported reserves (http://gofossilfree.org/top-200/). $\Delta \mathrm{Var}$ is the difference between each portfolio's variance and the variance of the FTSE 100 market portfolio. $* * *$ p $<0.01, * * \mathrm{p}<0.05$, * $\mathrm{p}<0.10$, with ${ }^{\mathrm{F}}$ denoting the F-test for equality of variances and ${ }^{\mathrm{LW}}$ the robust Ledoit-Wolf (2011) alternative using the studentized time series bootstrapping procedure with 5,000 resamples. $\Delta$ Sharpe is the difference between each portfolio's Sharpe ratio and that of the FTSE 100 market portfolio. ${ }^{\mathrm{JK}}$ denotes the Jobson-Korkie (1981) test of equal Sharpe ratios and ${ }^{\mathrm{LW}}$ the robust Ledoit-Wolf (2008) alternative using the studentized time series bootstrapping procedure with 5,000 resamples. 
Table A.8: Risk-adjusted return performance of FTSE 100 fossil fuel portfolios (Carhart model, 1996-2016)

\begin{tabular}{|c|c|c|c|c|c|c|}
\hline \multicolumn{4}{|c|}{$S I C$} & \multicolumn{3}{|l|}{ CU200 } \\
\hline Portfolio: & Coal & Oil and gas & All fossil fuels & Coal & Oil and gas & All fossil fuels \\
\hline MktRf & $\begin{array}{l}0.5857 * * * \\
(0.1401)\end{array}$ & $\begin{array}{l}0.0627 \\
(0.0878)\end{array}$ & $\begin{array}{l}0.1214 \\
(0.0896)\end{array}$ & $\begin{array}{l}0.6475^{* * * *} \\
(0.1245)\end{array}$ & $\begin{array}{l}0.1560^{*} \\
(0.0929)\end{array}$ & $\begin{array}{l}0.2258 * * \\
(0.0918)\end{array}$ \\
\hline SMB & $\begin{array}{l}0.3057 \\
(0.2361)\end{array}$ & $\begin{array}{l}-0.1622 \\
(0.1235)\end{array}$ & $\begin{array}{l}-0.1384 \\
(0.1216)\end{array}$ & $\begin{array}{l}0.4083 \\
(0.2505)\end{array}$ & $\begin{array}{l}-0.1319 \\
(0.1395)\end{array}$ & $\begin{array}{l}-0.0754 \\
(0.1397)\end{array}$ \\
\hline HML & $\begin{array}{l}0.6166 * * * \\
(0.1903)\end{array}$ & $\begin{array}{l}0.3818^{* * *} \\
(0.1107)\end{array}$ & $\begin{array}{l}0.4162^{* * * *} \\
(0.1108)\end{array}$ & $\begin{array}{l}0.5800^{* * * *} \\
(0.1959)\end{array}$ & $\begin{array}{l}0.4021^{* * *} \\
(0.1176)\end{array}$ & $\begin{array}{l}0.4495^{* * * *} \\
(0.1148)\end{array}$ \\
\hline WML & $\begin{array}{l}0.1496 \\
(0.1541)\end{array}$ & $\begin{array}{l}0.0461 \\
(0.0671)\end{array}$ & $\begin{array}{l}0.0587 \\
(0.0707)\end{array}$ & $\begin{array}{l}0.0308 \\
(0.1894)\end{array}$ & $\begin{array}{l}0.0650 \\
(0.0685)\end{array}$ & $\begin{array}{l}0.0651 \\
(0.0815)\end{array}$ \\
\hline Alpha & $\begin{array}{l}0.0052 \\
(0.0052)\end{array}$ & $\begin{array}{l}-0.0009 \\
(0.0025)\end{array}$ & $\begin{array}{l}-0.0010 \\
(0.0024)\end{array}$ & $\begin{array}{l}0.0027 \\
(0.0052)\end{array}$ & $\begin{array}{l}-0.0013 \\
(0.0026)\end{array}$ & $\begin{array}{l}-0.0023 \\
(0.0025)\end{array}$ \\
\hline $\begin{array}{l}\mathrm{N} \\
\mathrm{R}^{2}\end{array}$ & $\begin{array}{l}221 \\
0.1257\end{array}$ & $\begin{array}{l}245 \\
0.1060\end{array}$ & $\begin{array}{l}245 \\
0.1227\end{array}$ & $\begin{array}{l}221 \\
0.1501\end{array}$ & $\begin{array}{l}245 \\
0.1125\end{array}$ & $\begin{array}{l}245 \\
0.1320\end{array}$ \\
\hline
\end{tabular}

This table reports the results from regressing the monthly excess returns on the zero-investment portfolio with a long position in the fossil fuel portfolios and a corresponding short position in the FTSE 100 market portfolio excluding fossil fuels on the Carhart (1997) UK factors using OLS. The SIC industry definition includes SIC 12, 3532 (coal) and SIC 13, 291, 3533, 46, and 492 (oil and gas). CU200 is the July 2016 Carbon Underground 200 list from Fossil Free Indexes LLC of the 100 largest coal companies and 100 largest oil and gas companies based on reported reserves (http://gofossilfree.org/top-200/). Alpha is the intercept, indicating relative out- or underperformance. MktRf, SMB, HML, and WML are the coefficients on the Market, Size, Book-to-Market, and Momentum factors respectively. N is the number of monthly return observations. Newey-West (1987) heteroskedasticity and autocorrelation consistent (HAC) standard errors are in parentheses. $* * * \mathrm{p}<0.01, * * \mathrm{p}<0.05, * \mathrm{p}<0.10$.

Table A.9: Risk-adjusted return performance of fossil-free FTSE 100 portfolios (Carhart model, 1996-2016)

\begin{tabular}{|c|c|c|c|c|c|c|}
\hline & \multicolumn{3}{|l|}{ SIC } & \multicolumn{3}{|l|}{ CU200 } \\
\hline Portfolio: & Coal & Oil and gas & All fossil fuels & Coal & Oil and gas & All fossil fuels \\
\hline MktRf & $\begin{array}{l}0.9863 * * * \\
(0.0029)\end{array}$ & $\begin{array}{l}0.9812 * * * \\
(0.0190)\end{array}$ & $\begin{array}{l}0.9614 * * * \\
(0.0211)\end{array}$ & $\begin{array}{l}0.9679 * * * \\
(0.0065)\end{array}$ & $\begin{array}{l}0.9606 * * * \\
(0.0196)\end{array}$ & $\begin{array}{l}0.9353 * * * \\
(0.0211)\end{array}$ \\
\hline SMB & $\begin{array}{l}-0.0025 \\
(0.0035)\end{array}$ & $\begin{array}{l}0.0345 \\
(0.0266)\end{array}$ & $\begin{array}{l}0.0323 \\
(0.0280)\end{array}$ & $\begin{array}{l}-0.0122^{*} \\
(0.0072)\end{array}$ & $\begin{array}{l}0.0281 \\
(0.0277)\end{array}$ & $\begin{array}{l}0.0162 \\
(0.0289)\end{array}$ \\
\hline HML & $\begin{array}{l}-0.0091^{* * *} \\
(0.0031)\end{array}$ & $\begin{array}{l}-0.0739 * * * \\
(0.0208)\end{array}$ & $\begin{array}{l}-0.0874^{* * *} \\
(0.0223)\end{array}$ & $\begin{array}{l}-0.0236^{* * *} \\
(0.0075)\end{array}$ & $\begin{array}{l}-0.0752^{* * *} \\
(0.0205)\end{array}$ & $\begin{array}{l}-0.0956^{* * *} \\
(0.0212)\end{array}$ \\
\hline WML & $\begin{array}{l}-0.0033 \\
(0.0030)\end{array}$ & $\begin{array}{l}-0.0210 \\
(0.0149)\end{array}$ & $\begin{array}{l}-0.0264 \\
(0.0174)\end{array}$ & $\begin{array}{l}-0.0061 \\
(0.0076)\end{array}$ & $\begin{array}{l}-0.0252 * \\
(0.0148)\end{array}$ & $\begin{array}{l}-0.0304 \\
(0.0192)\end{array}$ \\
\hline Alpha & $\begin{array}{l}0.0000 \\
(0.0001)\end{array}$ & $\begin{array}{l}0.0005 \\
(0.0006)\end{array}$ & $\begin{array}{l}0.0006 \\
(0.0006)\end{array}$ & $\begin{array}{l}0.0003 \\
(0.0002)\end{array}$ & $\begin{array}{l}0.0006 \\
(0.0006)\end{array}$ & $\begin{array}{l}0.0009 \\
(0.0006)\end{array}$ \\
\hline $\begin{array}{l}\mathrm{N} \\
\mathrm{R}^{2}\end{array}$ & $\begin{array}{l}245 \\
0.9985\end{array}$ & $\begin{array}{l}245 \\
0.9392\end{array}$ & $\begin{array}{l}245 \\
0.9293\end{array}$ & $\begin{array}{l}245 \\
0.9926\end{array}$ & $\begin{array}{l}245 \\
0.9401\end{array}$ & $\begin{array}{l}245 \\
0.9235\end{array}$ \\
\hline
\end{tabular}

This table reports the results from regressing the monthly excess returns on the zero-investment portfolio with a long position in the fossilfree FTSE 100 market portfolio and a short position in the unconstrained index on the Carhart (1997) UK factors using OLS. The SIC industry definition includes SIC 12, 3532 (coal) and SIC 13, 291, 3533, 46, and 492 (oil and gas). CU200 is the July 2016 Carbon Underground 200 list from Fossil Free Indexes LLC of the 100 largest coal companies and 100 largest oil and gas companies based on reported reserves (http://gofossilfree.org/top-200/). Alpha is the intercept, indicating relative out- or underperformance. MktRf, SMB, HML, and WML are the coefficients on the Market, Size, Book-to-Market, and Momentum factors respectively. Newey-West (1987) heteroskedasticity and autocorrelation consistent (HAC) standard errors are in parentheses. ${ }^{* * *} \mathrm{p}<0.01,{ }^{* *} \mathrm{p}<0.05,{ }^{*} \mathrm{p}<0.10$. 
Table A.10: Risk-adjusted return performance of fossil fuel portfolios (Carhart model with GARCH(1,1) specification, 1927-2016)

Mean specification: $R_{p, t}-R_{f, t}=\alpha_{p}+\beta_{p, m}\left(R_{m, t}-R_{f, t}\right)+\beta_{p, S M B} S M B_{t}+\beta_{p, H M L} H M L_{t}+\beta_{p, W M L} W M L_{t}+\varepsilon_{p, t}$

Variance specification: $h_{t}=\alpha_{0}+a_{1} \epsilon_{t-1}^{2}+a_{2} h_{t-1}^{2}$

\begin{tabular}{|c|c|c|c|c|c|c|}
\hline & SIC & & & CU200 & & \\
\hline Portfolio: & Coal & Oil and gas & All fossil fuels & Coal & Oil and gas & All fossil fuels \\
\hline MktRf & $0.1361^{* *}$ & $-0.0751^{* *}$ & $-0.0762^{* *}$ & -0.0919 & $-0.1781^{* * *}$ & $-0.1395 * *$ \\
\hline SMB & $\begin{array}{l}0.4684 * * * \\
(0.1493)\end{array}$ & $\begin{array}{l}(0.0304) \\
-0.3209 * * * \\
(0.0484)\end{array}$ & $\begin{array}{l}(0.0302) \\
-0.3079 * * * \\
(0.0479)\end{array}$ & $\begin{array}{l}(0.0820) \\
0.0073 \\
(0.1137)\end{array}$ & $\begin{array}{l}(0.0586) \\
-0.1023 \\
(0.1194)\end{array}$ & $\begin{array}{l}(0.0612) \\
-0.0888 \\
(0.1377)\end{array}$ \\
\hline HML & $\begin{array}{l}0.6906 * * * \\
(0.0897)\end{array}$ & $\begin{array}{l}0.3885^{* * * *} \\
(0.0489)\end{array}$ & $\begin{array}{l}0.3919 * * * \\
(0.0488)\end{array}$ & $\begin{array}{l}0.4485 * * * \\
(0.1559)\end{array}$ & $\begin{array}{l}0.4287 * * * \\
(0.0947)\end{array}$ & $\begin{array}{l}0.4780 * * * \\
(0.1066)\end{array}$ \\
\hline WML & $\begin{array}{l}-0.2494 * * * \\
(0.0733)\end{array}$ & $\begin{array}{l}0.0526 \\
(0.0396)\end{array}$ & $\begin{array}{l}0.0492 \\
(0.0395)\end{array}$ & $\begin{array}{l}-0.0355 \\
(0.0772)\end{array}$ & $\begin{array}{l}0.0382 \\
(0.0765)\end{array}$ & $\begin{array}{l}0.0365 \\
(0.0676)\end{array}$ \\
\hline Alpha & $\begin{array}{l}-0.0041^{* *} \\
(0.0018)\end{array}$ & $\begin{array}{l}0.0007 \\
(0.0010)\end{array}$ & $\begin{array}{l}0.0007 \\
(0.0010)\end{array}$ & $\begin{array}{l}-0.0014 \\
(0.0024)\end{array}$ & $\begin{array}{l}-0.0001 \\
(0.0021)\end{array}$ & $\begin{array}{l}-0.0003 \\
(0.0028)\end{array}$ \\
\hline$\alpha_{0}$ & $\begin{array}{l}0.0002 \\
(0.0002)\end{array}$ & $\begin{array}{l}0.0000 * \\
(0.0000)\end{array}$ & $\begin{array}{l}0.0000^{*} \\
(0.0000)\end{array}$ & $\begin{array}{l}0.0001 \\
(0.0001)\end{array}$ & $\begin{array}{l}0.0007 \\
(0.0009)\end{array}$ & $\begin{array}{l}0.0002 \\
(0.0003)\end{array}$ \\
\hline$a_{1}$ & $\begin{array}{l}0.2058^{*} \\
(0.1242)\end{array}$ & $\begin{array}{l}0.1310^{* * *} \\
(0.0368)\end{array}$ & $\begin{array}{l}0.1331^{* * *} \\
(0.0357)\end{array}$ & $\begin{array}{l}0.0801 * * * \\
(0.0238)\end{array}$ & $\begin{array}{l}0.5078 \\
(0.5718)\end{array}$ & $\begin{array}{l}0.2920 \\
(0.2763)\end{array}$ \\
\hline$a_{2}$ & $\begin{array}{l}0.7719 * * * \\
(0.1378)\end{array}$ & $\begin{array}{l}0.8462 * * * \\
(0.0448)\end{array}$ & $\begin{array}{l}0.8433 \text { *** } \\
(0.0439)\end{array}$ & $\begin{array}{l}0.9027 * * * \\
(0.0288)\end{array}$ & $\begin{array}{l}0.4011 \\
(0.5870)\end{array}$ & $\begin{array}{l}0.6939 \text { *** } \\
(0.2322)\end{array}$ \\
\hline $\mathrm{N}$ & 1,080 & 1,080 & 1,080 & 750 & 737 & 815 \\
\hline $\mathrm{R}^{2}$ & 0.1967 & 0.0892 & 0.0888 & 0.0402 & 0.0861 & 0.0936 \\
\hline
\end{tabular}

This table reports the quasi-maximum likelihood estimates (Bollerslev and Wooldridge, 1992) of the GARCH(1,1) Carhart (1997) regressions of the monthly excess returns on the six zero-investment portfolios with a long position in the fossil fuel portfolios and a corresponding short position in the CRSP market portfolio excluding fossil fuels on the Carhart (1997) US factors using OLS. The SIC industry definition includes SIC 12, 3532 (coal) and SIC 13, 291, 3533, 46, and 492 (oil and gas). CU200 is the July 2016 Carbon Underground 200 list from Fossil Free Indexes LLC of the 100 largest coal companies and 100 largest oil and gas companies based on reported reserves (http://gofossilfree.org/top-200/). Alpha is the intercept, indicating relative out- or underperformance. MktRf, SMB, HML, and WML are the coefficients on the Market, Size, Book-to-Market, and Momentum factors respectively. Standard errors appear in brackets. *** $\mathrm{p}<0.01, * * \mathrm{p}<0.05, * \mathrm{p}<0.10$.

Table A.11: Risk-adjusted return performance of fossil-free portfolios (Carhart model with GARCH(1,1) specification, 1927-2016)

Mean specification: $R_{p, t}-R_{f, t}=\alpha_{p}+\beta_{p, m}\left(R_{m, t}-R_{f, t}\right)+\beta_{p, S M B} S M B_{t}+\beta_{p, H M L} H M L_{t}+\beta_{p, W M L} W M L_{t}+\varepsilon_{p, t}$

Variance specification: $h_{t}=\alpha_{0}+a_{1} \epsilon_{t-1}^{2}+a_{2} h_{t-1}^{2}$

\begin{tabular}{|c|c|c|c|c|c|c|}
\hline & SIC & & & CU200 & & \\
\hline Portfolio: & Coal & Oil and gas & All fossil fuels & Coal & Oil and gas & All fossil fuels \\
\hline MktRf & $\begin{array}{l}0.9976 * * * \\
(0.0006)\end{array}$ & $\begin{array}{l}1.0023 * * * \\
(0.0035)\end{array}$ & $\begin{array}{l}1.0025 * * * \\
(0.0036)\end{array}$ & $\begin{array}{l}0.9973 * * * \\
(0.0006)\end{array}$ & $\begin{array}{l}0.9975^{* * * *} \\
(0.0006)\end{array}$ & $\begin{array}{l}0.9975^{* * *} \\
(0.0006)\end{array}$ \\
\hline SMB & $\begin{array}{l}-0.0038^{* * *} \\
(0.0011)\end{array}$ & $\begin{array}{l}0.0490 * * * \\
(0.0057)\end{array}$ & $\begin{array}{l}0.0478 * * * \\
(0.0057)\end{array}$ & $\begin{array}{l}-0.0031^{* * *} \\
(0.0011)\end{array}$ & $\begin{array}{l}-0.0022 * \\
(0.0011)\end{array}$ & $\begin{array}{l}-0.0023^{* *} \\
(0.0011)\end{array}$ \\
\hline HML & $\begin{array}{l}0.0006 \\
(0.0009)\end{array}$ & $\begin{array}{l}-0.0769 * * * \\
(0.0058)\end{array}$ & $\begin{array}{l}-0.0775^{* * *} \\
(0.0058)\end{array}$ & $\begin{array}{l}0.0022^{* *} \\
(0.0010)\end{array}$ & $\begin{array}{l}0.0015 \\
(0.0010)\end{array}$ & $\begin{array}{l}0.0015 \\
(0.0010)\end{array}$ \\
\hline WML & $\begin{array}{l}0.0019 * * * \\
(0.0007)\end{array}$ & $\begin{array}{l}-0.0000 \\
(0.0045)\end{array}$ & $\begin{array}{l}-0.0001 \\
(0.0046)\end{array}$ & $\begin{array}{l}0.0021^{* * * *} \\
(0.0008)\end{array}$ & $\begin{array}{l}0.0021^{* * * *} \\
(0.0008)\end{array}$ & $\begin{array}{l}0.0020 * * * \\
(0.0008)\end{array}$ \\
\hline Alpha & $\begin{array}{l}-0.0000 \\
(0.0000)\end{array}$ & $\begin{array}{l}0.0000 \\
(0.0002)\end{array}$ & $\begin{array}{l}0.0000 \\
(0.0002)\end{array}$ & $\begin{array}{l}-0.0000 \\
(0.0000)\end{array}$ & $\begin{array}{l}-0.0000 \\
(0.0000)\end{array}$ & $\begin{array}{l}-0.0000 \\
(0.0000)\end{array}$ \\
\hline$\alpha_{0}$ & $\begin{array}{l}0.0000 * \\
(0.0000)\end{array}$ & $\begin{array}{l}0.0000 * * * \\
(0.0000)\end{array}$ & $\begin{array}{l}0.0000 * * * \\
(0.0000)\end{array}$ & $\begin{array}{l}0.0000 \\
(0.0000)\end{array}$ & $\begin{array}{l}0.0000 \\
(0.0000)\end{array}$ & $\begin{array}{l}0.0000 \\
(0.0000)\end{array}$ \\
\hline$a_{1}$ & $\begin{array}{l}0.1625^{* * *} \\
(0.0269)\end{array}$ & $\begin{array}{l}0.1667 * * * \\
(0.0269)\end{array}$ & $\begin{array}{l}0.1658^{* * *} \\
(0.0266)\end{array}$ & $\begin{array}{l}0.1193^{* * *} \\
(0.0191)\end{array}$ & $\begin{array}{l}0.1152^{* * *} \\
(0.0172)\end{array}$ & $\begin{array}{l}0.1167 * * * \\
(0.0178)\end{array}$ \\
\hline$a_{2}$ & $\begin{array}{l}0.8600 * * * \\
(0.0202)\end{array}$ & $\begin{array}{l}0.7954 * * * \\
(0.0305)\end{array}$ & $\begin{array}{l}0.7966 * * * \\
(0.0300)\end{array}$ & $\begin{array}{l}0.8954 * * * \\
(0.0147)\end{array}$ & $\begin{array}{l}0.8993 * * * \\
(0.0132)\end{array}$ & $\begin{array}{l}0.8984 * * * \\
(0.0135)\end{array}$ \\
\hline $\begin{array}{l}\mathrm{N} \\
\mathrm{R}^{2}\end{array}$ & $\begin{array}{l}1,080 \\
0.9957\end{array}$ & $\begin{array}{l}1,080 \\
0.9866\end{array}$ & $\begin{array}{l}1,080 \\
0.9864\end{array}$ & $\begin{array}{l}1,080 \\
0.9957\end{array}$ & $\begin{array}{l}1,080 \\
0.9955\end{array}$ & $\begin{array}{l}1,080 \\
0.9955\end{array}$ \\
\hline
\end{tabular}

This table reports the quasi-maximum likelihood estimates (Bollerslev and Wooldridge, 1992) of the GARCH(1,1) Carhart (1997) regressions of the monthly excess returns on the six zero-investment portfolios with a long position in the fossil fuel portfolio and a short position in the fossil-free portfolio on the US factors from 1927-2016. The SIC industry definition includes SIC 12, 3532 (coal) and SIC 13, 291, 3533, 46, and 492 (oil and gas). CU200 is the July 2016 Carbon Underground 200 list from Fossil Free Indexes LLC of the 100 largest coal companies and 100 largest oil and gas companies based on reported reserves (http://gofossilfree.org/top-200/). Alpha is the intercept, indicating relative out- or underperformance. MktRf, SMB, HML, and WML are the coefficients on the Market, Size, Book-to-Market, and Momentum factors respectively. Standard errors appear in brackets. *** $\mathrm{p}<0.01$, ** $\mathrm{p}<0.05$, * $\mathrm{p}<0.10$. 